\title{
Adaptation of the Distal Convoluted Tubule of the Rat Structural and Functional Effects of Dietary Salt Intake and Chronic Diuretic Infusion
}

\author{
David H. Ellison, “ Heino Velázquez, ${ }^{\star}$ and Fred S. Wright** \\ With the technical assistance of Katherine Harvey \\ Departments of ${ }^{*}$ Medicine and ${ }^{\ddagger}$ Cellular and Molecular Physiology, Yale University School of Medicine, New Haven, \\ Connecticut 06510; and Veterans Administration Medical Center, West Haven, Connecticut 06516
}

\begin{abstract}
We studied the effects of dietary $\mathrm{NaCl}$ intake on the renal distal tubule by feeding rats high or low $\mathrm{NaCl}$ chow or by chronically infusing furosemide. Furosemide-treated animals were offered saline as drinking fluid to replace urinary losses. Effects of $\mathrm{NaCl}$ intake were evaluated using free-flow micropuncture, in vivo microperfusion, and morphometric techniques. Dietary $\mathrm{NaCl}$ restriction did not affect $\mathrm{NaCl}$ delivery to the early distal tubule but markedly increased the capacity of the distal convoluted tubule to transport $\mathrm{Na}$ and $\mathrm{Cl}$. Chronic furosemide infusion increased $\mathrm{NaCl}$ delivery to the early distal tubule and also increased the rates of $\mathrm{Na}$ and $\mathrm{Cl}$ transport above the rates observed in low $\mathrm{NaCl}$ diet rats. When compared with high $\mathrm{NaCl}$ intake alone, chronic furosemide infusion with saline ingestion increased the fractional volume of distal convoluted tubule cells by nearly $100 \%$, whereas dietary $\mathrm{NaCl}$ restriction had no effect. The results are consistent with the hypotheses that $(a)$ chronic $\mathrm{NaCl}$ restriction increases the transport ability of the distal convoluted tubule independent of changes in tubule structure, (b) high rates of ion delivery to the distal nephron cause tubule hypertrophy, and (c) tubule hypertrophy is associated with increases in ion transport capacity. They indicate that the distal tubule adapts functionally and structurally to perturbations in dietary $\mathrm{Na}$ and $\mathrm{Cl}$ intake.
\end{abstract}

\section{Introduction}

The distal tubule, the nephron segment between the region of the macula densa and the first junction with another tubule, ${ }^{1}$ normally reabsorbs $5-10 \%$ of the filtered sodium load $(1,2)$. The rate of absorption is known to vary under some circumstances. When extracellular fluid volume is expanded acutely,

Portions of this work were presented at the 1986 Annual Meeting of the American Society of Nephrology, Washington, DC (1987. Kidney Int. 31:432) and at the International Congress of Nephrology, London, England, July, 1987.

Address reprint requests to Dr. David H. Ellison, Division of Nephrology, Yale University School of Medicine, 2073 LMP, 333 Cedar Street, New Haven, CT.

Received for publication 15 December 1987 and in revised form 23 August 1988.

1. This definition of distal tubule, used in the micropuncture literature, differs from the anatomical definition of distal tubule, which includes the TAL and DCT but not the ICT.

J. Clin. Invest.

(C) The American Society for Clinical Investigation, Inc. $0021-9738 / 89 / 01 / 0113 / 14 \$ 2.00$

Volume 83, January 1989, 113-126 sodium reabsorption by this nephron segment increases proportionately $(1,2)$, an effect mediated primarily by changes in the sodium concentration of luminal fluid entering this segment (3). Effects of chronic changes in sodium balance caused by dietary $\mathrm{NaCl}$ excess or restriction on urinary sodium excretion generally have been attributed to alterations in ion transport by nephron segments beyond the superficial distal tubule $(1,2)$. Changes in dietary $\mathrm{NaCl}$ intake have not been shown to influence the capacity of the distal tubule to transport $\mathrm{Na}$ and $\mathrm{Cl}$ (4-6). Kaissling and co-workers, however, recently reported that dietary $\mathrm{NaCl}$ excess in rabbits led to hypertrophy of distal convoluted tubule cells (7). They suggested that dietary $\mathrm{NaCl}$ excess caused cellular hypertrophy by increasing sodium delivery to the distal tubule and therefore by stimulating sodium transport chronically. In support of this hypothesis, they subsequently demonstrated that chronic furosemide infusion to rats also caused hypertrophy of distal tubule cells (8). They argued that furosemide increased the delivery of $\mathrm{Na}$ to the early distal tubule by blocking $\mathrm{Na}$ absorption upstream in the thick ascending limb and they suggested that hypertrophy of distal tubule cells reflects an increase in the intrinsic capacity of this segment to reabsorb sodium $(8,9)$.

The mammalian distal tubule is morphologically and functionally heterogeneous. It is made up of three subsegments: the distal convoluted tubule (DCT), ${ }^{2}$ the connecting tubule (CNT), and the initial collecting tubule (ICT) (10-12). Although sodium and chloride are reabsorbed throughout the entire length of the distal tubule $(13,14)$, the pathways by which these ions traverse the epithelium and the factors that control rates of ion transport may differ in the three subsegments. In the DCT of rats, the majority of transcellular $\mathrm{Na}$ and $\mathrm{Cl}$ transport traverses an electroneutral, thiazide-sensitive $\mathrm{NaCl}$ cotransport pathway (13). In the ICT, most transcellular $\mathrm{Na}$ transport traverses an amiloride-sensitive conductive pathway $(13,14)$. Less is known about transport pathways in the CNT (2).

This series of experiments was designed to investigate the hypothesis that chronic alterations in $\mathrm{Na}$ and $\mathrm{Cl}$ delivery to the distal tubule (or extracellular fluid volume status) cause both structural and functional changes in cells of the distal convoluted tubule. To this end, rats were either fed diets with high or low $\mathrm{NaCl}$ content or given furosemide chronically. The results

2. Abbreviations used in this paper: AIF, artificial interstitial fluid; $C D$, collecting duct; CNT, connecting tubule; CTZ, chlorothiazide; DCT, distal convoluted tubule; E, excretion rate; ECF, extracellular fluid volume; FD, fractional delivery; Hct, hematocrit; ICT, initial collecting tubule; $J_{\mathrm{i}}$, transport of ion; $L_{\mathrm{V}}^{\mathrm{L}}$, fractional length of lumen, $L_{\mathrm{V}}^{\mathrm{T}}$, fractional length of tubule; $r$, luminal radius; $R$, tubule radius; SNGFR, single nephron glomerular filtration rate; TAL, thick ascending limb; $V$, flow; $V_{\mathrm{V}}^{\mathrm{C}}$, fractional volume of cells; $V_{\mathrm{V}}^{\mathrm{L}}$, fractional volume of lumen; $V_{\mathrm{V}}^{\mathrm{T}}$, fractional volume of tubule. 
indicate that both extracellular fluid volume and distal $\mathrm{Na}$ and $\mathrm{Cl}$ delivery independently affect the ability of the DCT to absorb $\mathrm{Na}$ and $\mathrm{Cl}$. Cell hypertrophy on the other hand was observed only when distal sodium and chloride delivery rates were high. The results suggest that ion transport by the DCT of the rat is regulated homeostatically.

\section{Methods}

Male Sprague-Dawley rats (Harlan Sprague-Dawley, Inc., Indianapolis, IN) weighing 200-300 g were divided into three groups: group 1 animals (high $\mathrm{NaCl}$ intake) were allowed free access to high $\mathrm{NaCl}$ chow (29.2 $\mathrm{g} \mathrm{NaCl}$ per kg chow, AIN-76-modified, ICN Biochemicals, Cleveland, $\mathrm{OH})^{3}$ and $\mathrm{NaCl}$ containing drinking fluid $(8 \mathrm{~g} \mathrm{NaCl} /$ liter $)$; group 2 animals (low $\mathrm{NaCl}$ intake) were allowed free access to low $\mathrm{NaCl}$ chow $(0.292 \mathrm{~g} \mathrm{NaCl}$ per kg chow, AIN-76-modified, ICN Biochemicals) and tap water; group 3 animals (furosemide infusion and high $\mathrm{NaCl}$ intake) received a constant intraperitoneal infusion of furosemide $(0.67 \mathrm{mmol} / \mathrm{kg}$ body wt per $\mathrm{d})$ via osmotic pump as described by Kaissling and co-workers (8). Group 3 animals were allowed free access to standard rat chow (Ralston Purina Co., St. Louis, MO) and both tap water and high-salt drinking fluid $(8 \mathrm{~g} /$ liter $\mathrm{NaCl}$, $1 \mathrm{~g} /$ liter $\mathrm{KCl}$ ).

To infuse furosemide, osmotic pumps (Alzet model 2MLl; Alza Corp., Palo Alto, CA) were loaded with furosemide solution $(125 \mathrm{~g} /$ liter) that had been alkalinized to $\mathrm{pH} 8.0$ with $1 \mathrm{M} \mathrm{NaOH}$ to enhance solubility. The pumps were implanted in the peritoneum during ketamine anesthesia $(100 \mathrm{mg} / \mathrm{kg}$ body wt ketamine, Ketaset; Bristol Myers, Syracuse, NY). Pump placement was considered successful if urine output rose markedly and urine osmolality fell on the day after surgery. Preliminary experiments indicated that $\mathrm{Na}$ and $\mathrm{Cl}$ transport by the kidney and distal tubule were unaffected by chronic infusion of vehicle alone via osmotic pumps. ${ }^{4}$

Groups 1 and 2 were maintained on the experimental diets for 7-14 d. Group 3 received furosemide for $7 \mathrm{~d}$. During this time period, body weight, fluid intake, urine volume, and urinary $\mathrm{Na}, \mathrm{K}$, and osmolality were determined in a subset of animals from each group. At the end of the experimental period, arterial blood was obtained during ketamine anesthesia in a subset of six animals from each group to measure $\mathrm{pH}, \mathrm{PCO}_{2}, \mathrm{HCO}_{3}, \mathrm{Na}, \mathrm{K}$, and $\mathrm{Cl}$.

\section{Micropuncture experiments}

Animals were anesthetized by intraperitoneal injection of 5-s-butyl-5ethyl-2-thiobarbituric acid (Inactin; Byk-Gulden, Constance, FRG) and prepared surgically for micropuncture as described previously (3, 15). Groups 1 and 2 received $100-110 \mathrm{mg} \cdot \mathrm{kg}$ body wt ${ }^{-1}$ Inactin, but because furosemide-treated animals are more sensitive to Inactin (8), group 3 animals received $50 \mathrm{mg} \cdot \mathrm{kg}$ body $\mathrm{wt}^{-1}$. The rats were placed on

3. The $\mathrm{NaCl}$ content of normal rat chow varies. The $\mathrm{NaCl}$ content of Purina rat chow is $\sim 10 \mathrm{~g} / \mathrm{kg}$ chow. Altromin, a chow used extensively in Germany, has $\sim 5 \mathrm{~g} \mathrm{NaCl} / \mathrm{kg}$ chow.

4. Urinary concentrations of $\mathrm{Na}$, urinary flow rate, and urinary osmolality were unaffected by treatment with vehicle alone. In five animals exposed to vehicle infusion by osmotic pump $[\mathrm{Na}]_{\mathrm{U}}=139 \pm 2.7 \mathrm{mM}$, urinary flow rate $=14.1 \pm 0.7 \mathrm{ml} / \mathrm{d}$, and urinary osmolality $=1550 \pm 42.7 \mathrm{mosm} / \mathrm{kg} \mathrm{H}_{2} \mathrm{O}$. These values are not significantly different from values obtained before pump placement: $[\mathrm{Na}]_{\mathrm{U}}=144 \pm 2.4$ $\mathrm{mM}$, urinary flow rate $=9 \pm 0.6 \mathrm{ml} / \mathrm{d}$, and urinary osmolality $=1,522 \pm 9.1 \mathrm{mosm} / \mathrm{kg} \mathrm{H}_{2} \mathrm{O}$ indicating that vehicle infusion alone did not affect transport at the whole kidney level. Rates of sodium and chloride transport by whole distal tubules $(295 \pm 54.5$ and $244 \pm 59.2$ $\mathrm{pmol} / \mathrm{min}$ ) are similar to values obtained previously in this laboratory and are intermediate between values obtained in groups 1 (high $\mathrm{NaCl}$ diet) and 2 (low $\mathrm{NaCl}$ diet) in these studies (see Table $\mathrm{V}$ ), indicating that vehicle infusion alone did not affect ion transport by the distal tubule. a heated table designed to maintain body temperature at $37^{\circ} \mathrm{C}$. The left jugular vein was cannulated for administering supplementary doses of Inactin if necessary and for infusion of a salt solution (see below).

Free-flow micropuncture. During free-flow micropuncture, animals were given fluid to replace surgical losses and maintain urine output close to preanesthesia levels. Animals in group 1 received $2 \mathrm{ml}$ during surgery and $13 \mathrm{ml} / \mathrm{kg}$ body wt per h of $140 \mathrm{mM} \mathrm{NaCl}, 4 \mathrm{mM} \mathrm{KCl}$ during micropuncture. Group 2 rats received $2 \mathrm{ml}$ during surgery followed by $18 \mathrm{ml} / \mathrm{kg}$ body wt per h of a low $\mathrm{NaCl}$ solution $(35 \mathrm{mM}$ $\mathrm{NaCl}, 1 \mathrm{mM} \mathrm{KCl}$ ). Group 3 animals received $3 \mathrm{ml}$ during surgery followed by $8 \mathrm{ml} / \mathrm{h}$ of $140 \mathrm{mM} \mathrm{NaCl}, 4 \mathrm{mM} \mathrm{KCl}$. Because osmotic pumps were removed during surgical preparation for micropuncture, the maintenance infusion solution for group 3 animals also contained $0.15 \mathrm{~g} /$ liter furosemide (designed to maintain a furosemide infusion rate similar to that present before anesthesia). Each animal received 50 $\mu \mathrm{Ci}$ of $\left[{ }^{3} \mathrm{H}\right]$ Inulin (New England Nuclear, Boston, MA) during surgical preparation followed by a maintenance infusion of $50-100 \mu \mathrm{Ci} / \mathrm{h}$.

To identify early distal tubules, colored saline (FD\&C Blue \#1; H. Kohnstamm \& Co., New York, NY) was injected into a segment of the proximal tubule using a small-tip pipette (outer diameter $<5 \mu \mathrm{m}$ ) and observed to flow downstream into the distal nephron. Tubules were selected for micropuncture if two distal segments reached the kidney surface. A micropipette (o.d. 8-12 $\mu \mathrm{m}$ ) containing stained (Sudan black) mineral oil was placed in the upstream portion of the first distal segment. An oil block ( $>4$ tubule diameters) was injected downstream, and a complete collection of tubule fluid was made during a timed interval of 5-15 min using minimal suction. The volume of each sample was measured in a constant-bore glass capillary $(0.1 \mathrm{~mm}$ i.d.) and the radioactivity was determined in a liquid scintillation counter (model 6893; Searle Analytic, Elk Grove Village, IL) using Optifluor (New England Nuclear) as the scintillation medium. Sodium, potassium, and chloride were determined as described below.

In vivo microperfusion. The preparation of animals for microperfusion was similar to the preparation described above except for fluid infusion. To minimize differences in interstitial fluid composition during microperfusion, all animals received saline solution during microperfusion $(140 \mathrm{mM} \mathrm{NaCl}, 4 \mathrm{mM} \mathrm{KCl})$. Groups 1 and 2 received 2 $\mathrm{ml}$ during surgery followed by $13 \mathrm{ml} / \mathrm{kg}$ body wt per h, and group 3 received $3 \mathrm{ml}$ during surgery followed by $13 \mathrm{ml} / \mathrm{kg}$ body wt per $\mathrm{h}$. Because this series of experiments was designed to assess the intrinsic ability of distal tubules to transport $\mathrm{Na}$ and $\mathrm{Cl}$ (the ability to transport sodium and chloride under similar conditions), furosemide was not added to the infusion solution during the microperfusion experiments.

Tubules with two distal segments at the kidney surface were selected for microperfusion as previously described (15). Briefly, a perfusion pipette attached to a servo-controlled microperfusion pump (Klaus Effenberger, Munich, FRG) was positioned in the upstream segment and set to deliver fluid at $15 \mathrm{nl} / \mathrm{min}$. A second pipette was used to place a long castor oil block in the proximal straight tubule. Withdrawal of this pipette allowed glomerular filtrate to escape to the surface of the kidney. A collection pipette was then inserted in the downstream segment, a column of stained (Sudan Black) mineral oil was injected and, using slight suction, collection of perfused fluid was initiated. Fluid was collected, usually without further suction, during a timed interval of 3-6 min. During these experiments, two different solutions were perfused in every tubule. After the first fluid collection was complete, the perfusion and collection pipettes were removed and the perfusion pipette replaced with a pipette that contained a different perfusion solution. A new collection pipette was then inserted at the collection site and a second collection was obtained as described above. The order of perfusion was alternated to avoid systematic errors due to recollection.

Perfusion solution 1 (artificial interstitial fluid [AIF]) contained (in millimolars) $150, \mathrm{Na} ; 4.5, \mathrm{~K} ; 110, \mathrm{Cl} ; 25, \mathrm{HCO}_{3} ; 19$, acetate; 1.5 phosphate; blue dye (FD\&C Blue \#1) and $\left[{ }^{14} \mathrm{C}\right]$ Inulin (New England Nuclear). Solution 2 contained, in addition, $10^{-3} \mathrm{M}$ chlorothiazide (CTZ; Merck Sharp \& Dohme, Rahway, NJ). The pH was 7.3 when bubbled with $5 \% \mathrm{CO}_{2} / 95 \% \mathrm{~N}_{2}$. The volume and radioactivity of both perfused and collected fluids were determined as described above. 


\section{Distal tubule morphology}

Fixation and processing. The perfusion fixation technique was modified from Kaissling and co-workers (8). During Inactin anesthesia, the distal aorta was exposed and cannulated below the renal arteries with polyethylene tubing filled with saline and connected to a pressure transducer. The aorta was ligated proximal to the renal arteries. Fixative was perfused into the aorta for $2-4 \mathrm{~min}$ at $175 \mathrm{mmHg}$. The inferior vena cava was nicked to allow drainage of perfusion fluid. The fixation solution contained 3\% glutaraldehyde (Electron Microscopy Sciences, Fort Washington, PA), and, in millimolars $100, \mathrm{Na} ; 100$, cacodylate; $4.5, \mathrm{Ca} ; 9, \mathrm{Cl} ; 2.6$, picric acid; and $25 \mathrm{~g}$ /liter polyvinyl pyrrolidone. The osmolality of the base solution (without glutaraldehyde) was 207 mosm $/ \mathrm{kg} \mathrm{H} \mathrm{H}_{2} \mathrm{O}$. The osmolality of the complete solution was 498 mosm $/ \mathrm{kg} \mathrm{H}_{2} \mathrm{O}$. After perfusion, the kidneys were removed, trimmed of all fat and adherent tissue, weighed, and cut into 2-mm-thick longitudinal sections. These sections remained in the fixative for $24 \mathrm{~h}$ after which $\sim 102-\mathrm{mm}^{3}$ blocks were cut from the superficial cortex and transferred to $0.05 \mathrm{M} \mathrm{Na}$ cacodylate.

Tissue sections were postfixed with $1 \%$ osmium tetroxide, dehydrated in increasing concentrations of alcohol, and embedded with random orientation in Epon. For light microscopy, $1-\mu \mathrm{m}$ sections were cut with a Cambridge-Huxley ultramicrotome and stained with toluidene blue and basic fuchsin. For electron microscopy, thin sections were stained with lead citrate and uranyl acetate and viewed using a Philips 301 electron microscope.

Morphometric procedures. At least three different blocks from each kidney were examined. $1-\mu \mathrm{m}$-thick sections were photographed at a magnification of 62.5 with an Olympus Model BH2 photomicroscope. Transparencies were viewed with a DL-2 Microfilm Reader (Jenoptik GmbH, Jena, GDR) at a final magnification of 600 . Glomeruli, proximal tubules, thick ascending limbs (TAL), DCT, CNT, and collecting ducts $(C D)$ were identified based on criteria described by several investigators $(10-12,16,17)$. When viewed by light microscopy, the DCT is cytologically homogeneous; its cells contain apical nuclei and basal striations (because mitochondria are located within the basolateral membrane interdigitations). In contrast, the $C D$ appears variegated, because of the presence of both intercalated and principal cells. The principal cells of the CD have few mitochondria associated with their basal infoldings giving them a zone of basal lucency when viewed using low-power magnification. Differentiation of CNT cells from DCT cells is not always possible at low-power magnification $(10,11)$, although CNT cells often can be differentiated from DCT cells by electron microscopy. For this reason, we defined the transition from DCT to CNT as the first appearance of intercalated cells, a criterion also chosen by others $(8,16)$. It must be acknowledged that intercalated cells have been observed in the DCT in the rat $(10,11)$. They appear infrequently, however, and defining the DCT as free of intercalated cells permits consistent results from low-power light micrographs, which are essential to provide a large enough sampling area to determine fractional volumes of the various nephron components.

Fractional volumes, fractional lengths, cell heights, and tubule volume per millimeter tubule length were determined morphometrically as described in the Appendix.

Tubule casts. In an additional group of rats prepared for micropuncture, distal tubules were identified, as described above and injected with a rubber compound (Microfil; Canton Bio-Medical Products, Boulder, $\mathrm{CO}$ ). The kidneys were removed and digested for 30-40 min at room temperature in $20 \% \mathrm{NaOH}$. The distal tubule casts were teased free of kidney tissue and outlined on paper by means of a Leitz drawing attachment over one ocular of a Leitz dissecting microscope. The length of a distal tubule, from the region of the macula densa to the junction with another tubule, was measured on the drawing.

\section{Analytical techniques}

Sodium and potassium were measured in urine, plasma, and bulk solutions by flame photometry (model 443 ; Instrumentation Laboratory, Inc., Lexington, MA). Sodium was measured in fluids collected during free-flow micropuncture and in vivo microperfusion by flame- less atomic absorption spectrometry (model 951/655; Instrumentation Laboratory, Inc., Lexington, MA) as previously described (3). Chloride was measured in urine, plasma, and bulk solutions and collected fluids by electrometric titration (model CM10; Radiometer America, Westlake, $\mathrm{OH}$, and model F25; World Precision Instruments, New Haven, CT). Arterial pH, $\mathrm{PCO}_{2}$, and $\mathrm{HCO}_{3}$ were determined on heparinized arterial blood (model 168; Corning Glass Works, Corning, NY). Osmolality was measured by vapor pressure depression (model $5100 \mathrm{C}$; Wescor, Inc., Logan, UT).

The perfusion rate $\left(V_{0}\right)$ for each tubule was calculated as $V_{0}=V_{\mathrm{L}}$ ([inulin $]_{L} /[\text { inulin }]_{0}$ ), where $V_{\mathrm{L}}$ is the rate of fluid collection at tubule length $\mathrm{L}$, and [inulin] $]_{L} /[\text { inulin }]_{0}$ is the ratio of radioactivities in collected and perfused fluids. Volume flux $\left(J_{\mathrm{V}}\right)$ was calculated as the difference between perfused and collected flow rates $\left(\mathrm{J}_{\mathrm{V}}=V_{0}-V_{\mathrm{L}}\right)$. Ion transport, $J_{\mathrm{i}}$, was determined as $J_{\mathrm{i}}=V_{0} \cdot[\mathrm{i}]_{0}-V_{\mathrm{L}} \cdot[\mathrm{i}]_{\mathrm{L}}$, where $V$ is flow rate, [i] is ion concentration, and the subscripts, 0 and $L$, denote perfusion and collection sites. Single nephron glomerular filtration rate (SNGFR) was calculated as the product of the tubule fluid/plasma radioactivity ratio and measured tubule fluid volume per unit time.

\section{Statistical procedures}

Results are expressed as means \pm SEM. Results from groups 1, 2, and 3 were compared by modified $t$ tests using the Bonferroni correction for multiple comparisons (18). For three comparisons, the critical levels of $\alpha$ were $0.0167(0.05 / 3)$ and $0.0033(0.01 / 3)$. Effects of chlorothiazide on ion concentrations, flow rate, and ion transport rates in individual tubules were assessed by paired $t$ test.

\section{Results}

Animals tolerated each of the three treatment regimens well. Animals in groups 1 and 2 gained weight throughout the treatment period. Animals in group 3 (furosemide) lost weight during the first $3 \mathrm{~d}$ of furosemide infusion; their weights remained below the prefurosemide levels and the cumulative weight loss by day 7 was $21.6 \pm 5.9 \mathrm{~g}$. Unlike results reported by Kaissling and co-workers (8), we observed no diarrhea among the furosemide-treated animals.

Table I shows the results of measurements made with rats in metabolic cages on day 7 of treatment. Although animals in group 3 were offered both saline and water, they drank saline almost exclusively. Urine output was more than five times higher in the furosemide-treated animals (group 3 ) than in the high $\mathrm{NaCl}$ diet group (group 1). Urine output tended to be slightly lower in the low $\mathrm{NaCl}$ diet group (group 2) than in group 1 . Urinary osmolality was not different between group 1 and 2 but was significantly lower in group 3 . The urinary $\mathrm{Na}$ concentration was significantly higher in groups 1 and 3 than in group 2. Urinary sodium excretion was very low in group 2, moderate in group 1 , and very high in group 3 . Urine $\mathrm{K}$ concentration did not differ between the three groups, but rates of $\mathrm{K}$ excretion were higher in group 3 than in group 1 and 2. Fig. 1 shows the time course of changes in urinary volume and osmolality in group 3 animals. Urinary osmolality fell to values close to isotonic the day after surgery and urinary output rose rapidly to its maximal level, with little change in urine output or osmolality throughout the $7 \mathrm{~d}$ of furosemide infusion.

Table II shows plasma electrolytes, measured at the end of the treatment period (day 14 for groups 1 and 2, day 7 for group 3). Plasma sodium concentration was significantly lower in the low $\mathrm{NaCl}$ diet group than in groups 1 and 3; plasma potassium concentration was lower in the furosemide-treated 
Table I. Fluid Intake, Urine Output, and Urine Electrolytes

\begin{tabular}{|c|c|c|c|c|c|c|}
\hline Treatment & $\begin{array}{c}1 \\
(10)\end{array}$ & $\begin{array}{c}2 \\
(9)\end{array}$ & $\begin{array}{c}3 \\
(9)\end{array}$ & 1 vs. 2 & 2 vs. 3 & 1 vs. 3 \\
\hline $\mathrm{H}_{2} \mathrm{O}(m l / d)$ & & $24.1 \pm 3.9$ & $18.7 \pm 4.7$ & ND & NS & ND \\
\hline Saline $(m l / d)$ & $34.2 \pm 5.0$ & & $173.2 \pm 12.3$ & ND & ND & $*$ \\
\hline$V(m l / d)$ & $30.7 \pm 2.6$ & $14.0 \pm 2.2$ & $158.3 \pm 8.6$ & NS & $*$ & $*$ \\
\hline $\mathrm{U}_{\text {osm }}\left(\mathrm{mosm} / \mathrm{kg} \mathrm{H}_{2} \mathrm{O}\right)$ & $1,248.0 \pm 115.5$ & $1,325.0 \pm 214.6$ & $402.9 \pm 8.9$ & NS & $*$ & $*$ \\
\hline$[\mathrm{Na}]_{\mathrm{U}}(m M)$ & $168.4 \pm 6.5$ & $0.5 \pm 0.1$ & $146.1 \pm 1.8$ & $*$ & $*$ & $*$ \\
\hline$[\mathrm{K}]_{\mathrm{U}}(m M)$ & $52.6 \pm 5.2$ & $59.9 \pm 11.9$ & $40.6 \pm 1.4$ & NS & NS & NS \\
\hline $\mathrm{E}_{\mathrm{Na}}(\mathrm{mmol} / \mathrm{d})$ & $5.2 \pm 0.5$ & $0.0 \pm 0.0$ & $23.4 \pm 1.2$ & $*$ & $*$ & $*$ \\
\hline $\mathrm{E}_{\mathrm{K}}(\mathrm{mmol} / d)$ & $1.5 \pm 0.2$ & $0.7 \pm 0.1$ & $6.5 \pm 0.4$ & NS & $*$ & $*$ \\
\hline
\end{tabular}

Treatment 1, high NaCl; treatment 2 , low NaCl; treatment 3 , furosemide. Values are means $\pm \mathrm{SE}$. Numbers in parentheses indicate number of animals. * indicates $P<0.01$. ND, not done. $P$ values for 1 vs. 2,2 vs. 3 , and 1 vs. 3 determined by modified $t$ test as described in Methods.

animals. Animals in group 3 (furosemide) developed significant metabolic alkalosis with low plasma chloride concentration and elevated plasma bicarbonate concentration and arterial $\mathrm{pH}$. There was also evidence of extracellular fluid volume contraction in group 3 , including elevations in the hematocrit (HCT), loss of weight (noted above), and lower SNGFR (see Table III), although anesthesia for micropuncture may have amplified the effects of furosemide on extracellular fluid volume.

Rates of ion delivery to the early distal tubule were determined in a series of free-flow micropuncture experiments. During these experiments, intravenous fluid administration was designed to maintain urinary $\mathrm{Na}$ and $\mathrm{Cl}$ excretion rates close to levels when awake (as shown in Table I). Group 3 animals also received continuous intravenous furosemide during these experiments to mimic the plasma concentrations obtained during osmotic pump infusion. During micropuncture, urinary flow rate was significantly higher in group 3

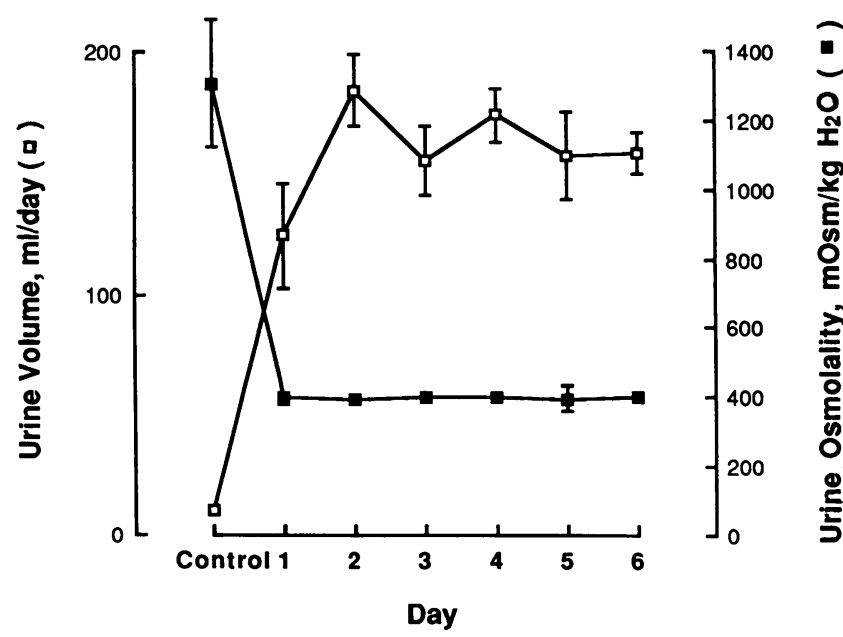

Figure 1. Effects of furosemide infusion on urine volume and osmolality. Data are means \pm SE. Control data obtained during $24 \mathrm{~h}$ before placement of osmotic pump. Experimental data (day 1-6) were obtained after a 12-h surgical recovery period. Empty boxes indicate urine volume (milliliters per day), filled boxes indicate urine osmolality (in milliosmolar per kilogram $\mathrm{H}_{2} \mathrm{O}$ ).
$(42.7 \pm 8.1 \mu \mathrm{l} / \mathrm{min})$ than in groups 1 and $2(6.2 \pm 1.6 \mu \mathrm{l} / \mathrm{min}$, and $5.6 \pm 3.0 \mathrm{ml} / \mathrm{min}$ respectively, $P<0.05)$. Urinary $\mathrm{Na}$ concentration was high in group 1 animals $(223 \pm 46.4 \mathrm{mM})$, low in group 2 animals $(4.9 \pm 0.7 \mathrm{mM})$, and close to plasma levels in group $3(134 \pm 2.3 \mathrm{mM})$. Rates of fluid administration thus maintained urinary fluid and electrolyte excretion during freeflow micropuncture close to levels observed when animals were awake.

Table III shows results obtained by free-flow micropuncture. The concentration of sodium entering the early distal tubule was not significantly different in the two groups with differing $\mathrm{Na}$ intake. On the other hand, the sodium concentration in the early distal tubule was higher in group 3, reflecting the inhibition by furosemide of electrolyte transport by the TAL. Similarly, the concentrations of chloride and potassium in fluid entering the distal tubule were not significantly different in groups 1 and 2 but were significantly higher in group 3 . The fluid flow rate in early distal tubules was significantly lower in the low $\mathrm{NaCl}$ than in the high $\mathrm{NaCl}$ animals. The flow rate in the furosemide-treated animals was intermediate between these values. Fig. 2 shows that $\mathrm{Na}$ and $\mathrm{Cl}$ delivery rates to the early distal tubule were higher in group 3 than in group 1 and $2(P<0.01)$. The fractional delivery of $\mathrm{Na}$ and $\mathrm{Cl}$ to the early distal tubule during furosemide infusion exceeded one third of the filtered load in this group, despite contraction of the extracellular fluid volume.

The ability of the DCT to transport $\mathrm{Na}$ and $\mathrm{Cl}$ when luminal and peritubular factors were controlled was determined in a series of in vivo microperfusion experiments. To reduce differences in plasma (and peritubular) electrolyte concentrations, all animals were infused intravenously with the same salt solution during microperfusion. Plasma concentrations of $\mathrm{Na}$ and $\mathrm{Cl}$ during microperfusion were not significantly different between the groups ([Na] and [Cl] in millimolars: group 1, $147 \pm 1.0$ and $100 \pm 1.1$; group $2,145 \pm 1.8$ and $97 \pm 0.4$; and group 3, 146 \pm 1.6 and 101 \pm 1.0 ). Luminal flow rate and ion composition were controlled by in vivo microperfusion and were the same for all three groups. Transport by the DCT segment was estimated as the portion of $\mathrm{Na}$ and $\mathrm{Cl}$ transport by whole distal tubules that was inhibited by CTZ. We have shown previously that $\mathrm{CTZ}$ blocks all transcellular $\mathrm{NaCl}$ transport by cells of the DCT in the rat (13). CTZ does not affect $\mathrm{Na}$ and $\mathrm{Cl}$ transport by the ICT $\left(13,14\right.$; see Discussion) ${ }^{5}$ 
Table II. Plasma Electrolyte Concentrations, and Arterial Blood $\mathrm{pH}, \mathrm{PCO}_{2}$, and $\mathrm{Hct}$

\begin{tabular}{|c|c|c|c|c|c|c|}
\hline Treatment & $\begin{array}{c}1 \\
(6)\end{array}$ & $\begin{array}{c}2 \\
(6)\end{array}$ & $\begin{array}{c}3 \\
(6)\end{array}$ & 1 vs. 2 & 2 vs. 3 & 1 vs. 3 \\
\hline$[\mathrm{Na}](m M)$ & $144.1 \pm 0.1$ & $141.6 \pm 0.4$ & $144.1 \pm 0.2$ & $\neq$ & $\neq$ & NS \\
\hline$[\mathrm{K}](m M)$ & $3.8 \pm 0.1$ & $3.6 \pm 0.2$ & $3.2 \pm 0.1$ & NS & NS & $*$ \\
\hline$[\mathrm{Cl}](m M)$ & $104.4 \pm 1.1$ & $98.3 \pm 0.8$ & $93.7 \pm 0.9$ & $\ddagger$ & $\neq$ & $\neq$ \\
\hline$\left[\mathrm{HCO}_{3}\right](m M)$ & $21.6 \pm 0.7$ & $22.9 \pm 0.5$ & $28.8 \pm 0.9$ & NS & $\ddagger$ & $\ddagger$ \\
\hline $\mathrm{pH}$ & $7.35 \pm 0.03$ & $7.39 \pm 0.02$ & $7.48 \pm 0.02$ & NS & $\ddagger$ & $*$ \\
\hline $\mathrm{PCO}_{2}(m m H g)$ & $39.7 \pm 1.6$ & $38.0 \pm 1.6$ & $38.7 \pm 0.9$ & NS & NS & NS \\
\hline Hct (\%) & $43.8 \pm 1.2$ & $47.4 \pm 0.8$ & $51.3 \pm 1.0$ & NS & $*$ & $\ddagger$ \\
\hline
\end{tabular}

Treatment 1, high $\mathrm{NaCl}$; treatment 2, low $\mathrm{NaCl}$; treatment 3, furosemide. Values are means $\pm \mathrm{SE}$. Numbers in parentheses indicate number of animals. ${ }^{*}$ indicates $P<0.05{ }^{\ddagger}$ indicates $P<0.01$. $P$ values for 1 vs. 2,2 vs. 3, and 1 vs. 3 determined by modified $t$ testing as described in Methods.

Table IV shows ion concentrations and volume flow rates in the three treatment groups during perfusion with the control and chlorothiazide containing solutions. Volume absorption was significantly different from zero $(1.1 \pm 0.2 \mathrm{nl} / \mathrm{min})$ in group 3 but not in group 1 or 2 . Chlorothiazide significantly reduced volume absorption in group 3 animals $(-0.53 \pm 0.22 \mathrm{nl} / \mathrm{min}$, $P<0.05$ ).

Table $\mathrm{V}$ compares rates of $\mathrm{Na}$ and $\mathrm{Cl}$ transport in group 1 , 2 , and 3 when tubules were perfused with the same solution. Compared with group 1 (high $\mathrm{NaCl}$ diet), sodium transport was increased in both low $\mathrm{NaCl}$ animals (group 2) and furosemide animals (group 3). When the two volume-contracted groups were compared (group 2 and 3), rates of sodium absorption were significantly higher in furosemide animals than in low $\mathrm{NaCl}$ animals. Rates of $\mathrm{Cl}$ transport were also increased in groups 2 and 3. They were highest in the furosemide group, intermediate in the low $\mathrm{NaCl}$ group and lowest in the high

5. In experiments by ourselves (13) and others (14), it has not been possible to rule out the possibility that $\mathrm{CTZ}$ affects $\mathrm{Na}$ and $\mathrm{Cl}$ transport by the CNT. Thus, it is possible that the portion of ion transport inhibited by $\mathrm{CTZ}$ includes some transport by the connecting tubule as well as by the DCT.
$\mathrm{NaCl}$ group. Chlorothiazide reduced $\mathrm{Na}$ and $\mathrm{Cl}$ absorption significantly in all three groups of animals. Fig. 3 shows transport by the DCT estimated as the chlorothiazide sensitive fraction of $\mathrm{Na}$ and $\mathrm{Cl}$ transport (the difference between transport rates during perfusion with control and thiazide containing solutions). The CTZ-sensitive fraction of $\mathrm{Na}$ and $\mathrm{Cl}$ transport was significantly higher in group 3 (furosemide) than in group 1 (High $\mathrm{NaCl})(P<0.01)$. The chlorothiazide sensitive fraction of $\mathrm{Na}$ transport was also greater in group 2 (low $\mathrm{NaCl}$ ) than in group $1(P<0.01)$.

The effects of dietary $\mathrm{NaCl}$ intake and furosemide on distal tubule cell structure were assessed using light microscopic examination of tissue sections and rubber casts of distal tubules. The effects of treatment on kidney weight and nephron length are shown in Table VI. Left kidneys from high $\mathrm{NaCl}$ diet animals were heavier than left kidneys from furosemide treated animals, but the treatment regimens did not affect the length of distal tubules significantly. Table VII and Fig. 4 show the morphometrically determined effects of each treatment regimen on the fractional volumes of nephron segments. The fractional volumes of glomeruli and proximal tubules (data not shown) were not affected significantly by the treatment regimens. The fractional volumes of DCT, CNT, and ICT

Table III. Results of Free-Flow Distal Micropuncture

\begin{tabular}{|c|c|c|c|c|c|c|}
\hline Treatment & $\begin{array}{c}1 \\
(15 / 4)\end{array}$ & $\begin{array}{c}2 \\
(13 / 3)\end{array}$ & $\begin{array}{c}3 \\
(13 / 4)\end{array}$ & 1 vs. 2 & 2 vs. 3 & 1 vs. 3 \\
\hline$[\mathrm{Na}]_{\mathrm{ED}}(m M)$ & $42.9 \pm 2.5$ & $47.1 \pm 3.9$ & $110.3 \pm 3.6$ & NS & $\neq$ & $\ddagger$ \\
\hline$[\mathrm{Cl}]_{\mathrm{ED}}(m M)$ & $34.0 \pm 1.8$ & $29.3 \pm 4.9$ & $104.8 \pm 3.3$ & NS & $\ddagger$ & $\ddagger$ \\
\hline$[\mathrm{K}]_{\mathrm{ED}}(m M)$ & $1.4 \pm 0.4$ & $2.5 \pm 0.4$ & $4.2 \pm 0.2$ & NS & $\neq$ & $\neq$ \\
\hline$V_{\mathrm{ED}}(\mathrm{nl} / \mathrm{min})$ & $9.4 \pm 0.4$ & $7.2 \pm 0.7$ & $8.2 \pm 0.8$ & $*$ & NS & NS \\
\hline $\mathrm{Na}_{\mathrm{ED}}(p m o l / m i n)$ & $411.1 \pm 37.6$ & $327.1 \pm 35.5$ & $927.1 \pm 121.8$ & NS & $\neq$ & $\neq$ \\
\hline $\mathrm{Cl}_{\mathrm{ED}}(p m o l / m i n)$ & $323.6 \pm 25.5$ & $205.0 \pm 41.0$ & $876.8 \pm 111.0$ & NS & $\neq$ & $\neq$ \\
\hline $\mathrm{K}_{\mathrm{ED}}(\mathrm{pmol} / \mathrm{min})$ & $13.5 \pm 3.6$ & $16.6 \pm 2.4$ & $35.4 \pm 4.8$ & NS & $\neq$ & $\ddagger$ \\
\hline SNGFR $(n l / m i n)$ & $38.2 \pm 2.2$ & $35.4 \pm 2.2$ & $18.4 \pm 1.6$ & NS & $\mp$ & $\ddagger$ \\
\hline
\end{tabular}

Treatment 1, high NaCl; treatment 2, low NaCl; treatment 3, furosemide. Numbers in parentheses indicate number of tubules per number of rats. $[\mathrm{Na}]_{\mathrm{ED}},[\mathrm{Cl}]_{\mathrm{ED}}$, and $[\mathrm{K}]_{\mathrm{ED}}$ indicate concentrations of $\mathrm{Na}, \mathrm{Cl}$, and $\mathrm{K}$ in fluid arriving at the early distal tubule. $\mathrm{V}_{\mathrm{ED}}$ indicates early distal fluid flow rate. $\mathrm{Na}_{\mathrm{ED}}, \mathrm{Cl}_{\mathrm{ED}}$, and $\mathrm{K}_{\mathrm{ED}}$ indicate rates of $\mathrm{Na}, \mathrm{Cl}$, and $\mathrm{K}$ delivery to the early distal tubule. $\mathrm{FD}_{\mathrm{Na}}, \mathrm{FD}_{\mathrm{Cl}}$, and $\mathrm{FD}_{\mathrm{K}}$ indicate fractional delivery of $\mathrm{Na}, \mathrm{Cl}$ and $\mathrm{K}$ to the early distal tubule. ${ }^{*}$ indicates $P<0.05$. ${ }^{\ddagger}$ indicates $P<0.01 . P$ values for 1 vs. 2,2 vs. 3 , and 1 vs. 3 are determined by modified $t$ test as described in Methods. 


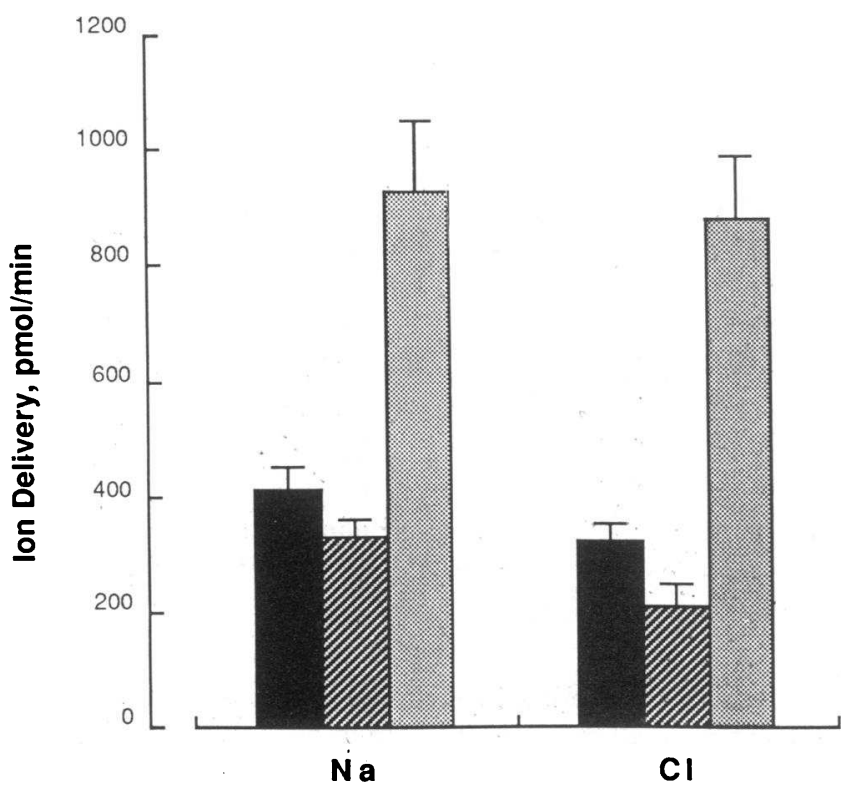

Figure 2. Rates of ion delivery ( $+\mathrm{SE}$ ) to the early distal tubule during free flow micropuncture. There were 15 nephrons in 4 rats in group 1,13 nephrons in 3 rats in group 2, and 13 nephrons in 4 rats in group 3. Ion delivery (see Table III) is significantly higher $(P<0.01)$ in group 3 than in groups 1 and 2 . In this and subsequent figures, $\square$, high $\mathrm{NaCl}$; , low $\mathrm{NaCl} ; \square$, furosemide.

were not significantly different in the high and low $\mathrm{NaCl}$ diet groups (group 1 and 2). On the other hand, fractional cell volumes of DCT, CNT, and ICT were significantly greater in group 3 animals than in groups 1: fractional cell volumes of DCT and ICT were also significantly greater in group 3 than in group 2. The fractional volume of DCT cells was approximately twice as large in group 3 as in groups 1 and 2. In kidneys from group 3 animals, tubule cells throughout the distal nephron were large and often appeared bizarre in shape (see Fig. 5). In the CNT and ICT, intercalated, principal, and connecting tubule cells all appeared hypertrophied. ${ }^{6}$ Treat-

6. Fractional volume was measured in these experiments. Because cell number could not be assessed directly, it is impossible to determine whether an increase in cell volume, cell number or both is responsible for the increased fractional volume. Based on measurements of basolateral membrane amplification, Kaissling and co-workers (8) suggested that both cell number and cell size were increased by chronic furosemide therapy. Measured lengths of whole tubules were not different in the three groups in this study. ment with furosemide also made distinguishing characteristics of DCT, CNT, and ICT cells much more obvious. Although treatment did not affect the fractional luminal volume of any individual distal segment significantly (TAL luminal volume was affected), when values from DCT, CNT, and CD were pooled and analyzed as a group, fractional luminal volume was reduced significantly by low $\mathrm{NaCl}$ diet.

Electron microscopy confirmed the results of light microscopic study. The appearance of DCT cells was similar in groups 1 and 2. On the other hand, DCT cells from furosemide-treated animals (group 3) were clearly taller than cells of groups 1 and 2 (see Fig. 6). In group 3 animals, mitochondria within the basolateral cell processes were longer and the height of the cell processes themselves was greater. Nuclei in DCT cells of group 3 animals appeared larger and exhibited more circular profiles. As reported by Kaissling and co-workers (8), DCT cell nuclei from furosemide-treated animals appeared to be sunk more deeply into the cell. All cells of the distal nephron (DCT cells, CNT cells, principal cells, and intercalated cells) were hypertrophied in group 3 animals. Intercalated cells were especially prominent in this group, often bulging out into the tubule lumen.

Morphometric techniques (described in the Appendix) were also used to estimate luminal and tubule radii and cell heights in segments of the distal tubule. Table VIII and Fig. 7 show results of these measurements. The luminal radius of TAL was significantly smaller in low $\mathrm{NaCl}$ diet animals than in high $\mathrm{NaCl}$ diet animals. Further, TAL cell heights were significantly lower in animals treated with furosemide than in low $\mathrm{NaCl}$ diet animals. Although they did not quite reach statistical significance, cell heights and epithelial volumes per millimeter tubule length of DCT and CNT tended to be greater in group 3 than in group 1 animals. In the collecting duct, cell height and epithelial volume per millimeter tubule length were significantly greater in group 3 (furosemide) than in either group 1 or 2 .

\section{Discussion}

Although sodium and chloride absorption by the distal tubule varies directly with delivered load under a variety of circumstances $(1,3,19,20)$, it has been accepted generally that the intrinsic ability of the distal tubule to absorb $\mathrm{Na}$ and $\mathrm{Cl}$ is not influenced by perturbations of extracellular fluid (ECF) volume $(1,21)$. Recently, Kaissling and co-workers reported that rabbits fed high $\mathrm{NaCl}$ diets develop hypertrophy of DCT cells $(8,22)$. They suggested that increased $\mathrm{Na}$ delivery to the distal

Table IV. Results of In Vivo Microperfusion: Volume Flow Rates and Ion Concentrations

\begin{tabular}{|c|c|c|c|c|c|c|}
\hline & \multicolumn{2}{|c|}{ Group 1} & \multicolumn{2}{|c|}{ Group 2} & \multicolumn{2}{|c|}{ Group 3} \\
\hline & Control & CTZ & Control & CTZ & Control & CTZ \\
\hline$V_{0}(n l / \min )$ & $13.9 \pm 0.3$ & $13.5 \pm 0.2$ & $14.2 \pm 0.2$ & $13.7 \pm 0.7$ & $14.6 \pm 0.4$ & $13.7 \pm 0.4$ \\
\hline$V_{\mathrm{L}}(n l / \min )$ & $14.3 \pm 0.3$ & $13.4 \pm 0.1$ & $14.1 \pm 0.2$ & $13.7 \pm 0.6$ & $13.6 \pm 0.5$ & $13.2 \pm 0.3$ \\
\hline$[\mathrm{Na}]_{\mathrm{L}}(m M)$ & $127.8 \pm 2.7$ & $139.3 \pm 1.7^{*}$ & $123.1 \pm 2.4$ & $138.9 \pm 1.7^{\ddagger}$ & $119.3 \pm 2.9$ & $134.3 \pm 3.1^{*}$ \\
\hline$[\mathrm{Cl}]_{\mathrm{L}}(m M)$ & $100.3 \pm 2.1$ & $114.6 \pm 0.7^{\ddagger}$ & $90.7 \pm 1.6$ & $110.1 \pm 1.3^{\ddagger}$ & $88.8 \pm 2.6$ & $114.3 \pm 1.4^{\ddagger}$ \\
\hline
\end{tabular}

Treatment 1, high NaCl; treatment 2 , low $\mathrm{NaCl}$; treatment 3, furosemide. Values are means $\pm \mathrm{SE}$. Numbers in parentheses indicate number of tubules per number of rats. ${ }^{*}$ indicates control vs. CTZ $P<0.01,{ }^{\ddagger}$ indicates $P<0.001$. $P$ values determined by unpaired $t$ test. 
Table V. Rates of Sodium and Chloride Transport by Distal Tubules

\begin{tabular}{|c|c|c|c|c|c|c|}
\hline Treatment & 1 & 2 & 3 & 1 vs. 2 & 2 vs. 3 & 1 vs. 3 \\
\hline \multicolumn{7}{|l|}{$J_{\mathrm{Na}}$} \\
\hline Control $(\mathrm{pmol} / \mathrm{min})$ & $203.5 \pm 27.78$ & $379.6 \pm 28.79$ & $527.3 \pm 47.0$ & $*$ & $\neq$ & $*$ \\
\hline $\mathrm{CTZ}(\mathrm{pmol} / \mathrm{min})$ & $120.62 \pm 20.22$ & $154.4 \pm 36.48$ & $288.4 \pm 38.4$ & NS & $\neq$ & $*$ \\
\hline$\Delta(\mathrm{pmol} / \mathrm{min})$ & $82.9 \pm 24.1$ & $225.2 \pm 35.24$ & $288.4 \pm 38.4$ & $*$ & NS & $*$ \\
\hline \multicolumn{7}{|l|}{$J_{\mathrm{C}}$} \\
\hline Control $(\mathrm{pmol} / \mathrm{min})$ & $168.6 \pm 29.0$ & $303.7 \pm 36.8$ & $483.4 \pm 44.9$ & $\ddagger$ & * & $*$ \\
\hline CTZ $(p m o l / m i n)$ & $33.3 \pm 15.3$ & $48.9 \pm 23.3$ & $140.5 \pm 22.6$ & NS & $\ddagger$ & * \\
\hline$\Delta(\mathrm{pmol} / \mathrm{min})$ & $135.3 \pm 34.2$ & $254.8 \pm 35.0$ & $343.4 \pm 46.5$ & NS & NS & * \\
\hline
\end{tabular}

Treatment 1, high NaCl; treatment 2 , low $\mathrm{NaCl}$; treatment 3 , furosemide. $\Delta$, Control $-\mathrm{CTZ}$. Values are means $\pm \mathrm{SE}$. Number of tubules and number of rats given in Table IV. ${ }^{*}$ indicates $P<0.01{ }^{\ddagger}$ indicates $P<0.05$. $P$ values for 1 vs. 2,2 vs. 3 , and 1 vs. 3 determined by modified $t$ test as described in Methods.

tubule stimulates cell growth by increasing $\mathrm{Na}$ and $\mathrm{Cl}$ transport. This series of experiments was designed to examine three hypotheses: (a) chronic alterations of extracellular fluid volume influence the structure of the DCT and/or its intrinsic ability to absorb $\mathrm{Na}$ and $\mathrm{Cl} ;(b)$ the renal effects of changes in extracellular fluid volume are mediated, at least in part, by changes in distal ion delivery; and $(c)$ structural alterations of DCT cells reflect changes in their intrinsic ability to transport $\mathrm{Na}$ and $\mathrm{Cl}$. The results indicate that chronic ECF depletion increases the ability of the DCT of the rat to absorb $\mathrm{Na}$ and $\mathrm{Cl}$. They show that ion transport rates may change without attendant structural alterations. They also indicate that, when structural changes do occur, they are associated with additional

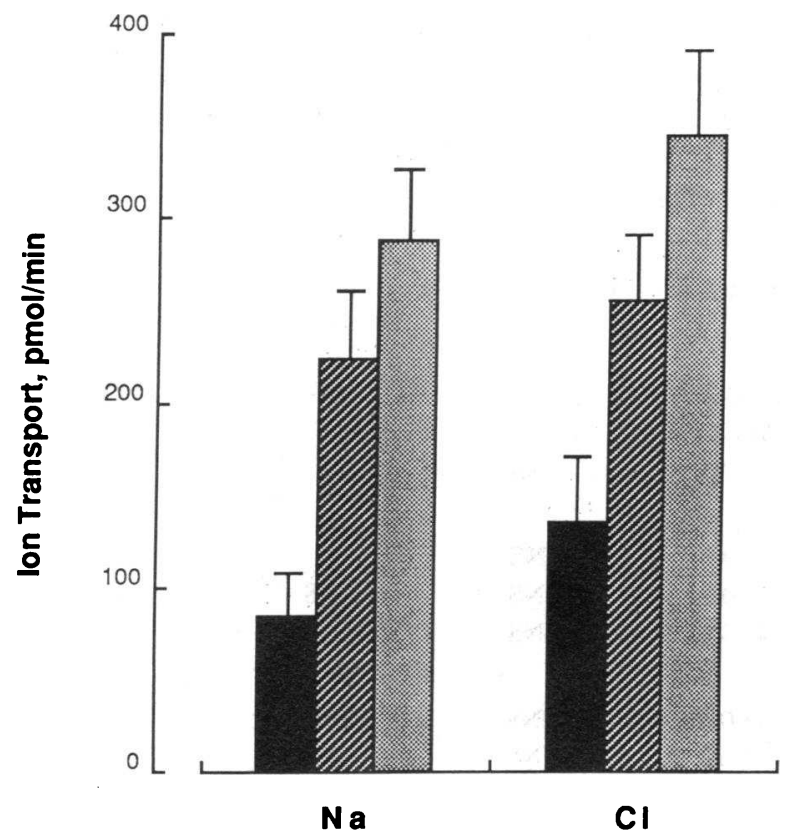

Figure 3. Ion transport by DCT (+SE) estimated as the CTZ-sensitive portion of $\mathrm{Na}$ and $\mathrm{Cl}$ transport by the distal tubule. There were 17 nephrons in 8 animals in group 1, 16 nephrons in 7 animals in group 2, and 14 nephrons in 8 animals in group 3. Sodium absorption was significantly greater $(P<0.01)$ in groups 2 and 3 (low $\mathrm{NaCl}$ and furosemide) than in group 1 (high $\mathrm{NaCl}$ ). Chloride absorption was significantly greater in group 3 (furosemide, $P<0.05$ ) than in group 1 (high $\mathrm{NaCl}$ ). functional changes, changes that may be caused by chronic alterations in transcellular ion transport rates.

In these experiments, two maneuvers were used to alter urinary $\mathrm{Na}$ and $\mathrm{Cl}$ excretion and extracellular fluid volume in the same species, high or low dietary $\mathrm{NaCl}$ intake and infusion of the diuretic furosemide. As expected, urinary $\mathrm{Na}$ excretion rates were lower in group 2 than in group 1 and were extraordinarily high in group 3 (see Table II). Further, compared with high $\mathrm{NaCl}$ diet animals, low $\mathrm{NaCl}$ diet animals appeared slightly volume contracted (higher Hct, similar SNGFR) and furosemide animals appeared significantly volume contracted (highest Hct, low SNGFR). The results of the free-flow micropuncture experiments indicate that dietary $\mathrm{NaCl}$ intake and furosemide infusion both affected distal $\mathrm{Na}$ delivery, as well as urinary $\mathrm{Na}$ excretion. Although sodium and chloride concentrations in distal tubule fluid were not significantly different in groups 1 and 2, distal $\mathrm{Na}$ delivery (both fractional and absolute) tended to be higher in group 1 because of the significantly higher flow rate in this group. These results confirm earlier

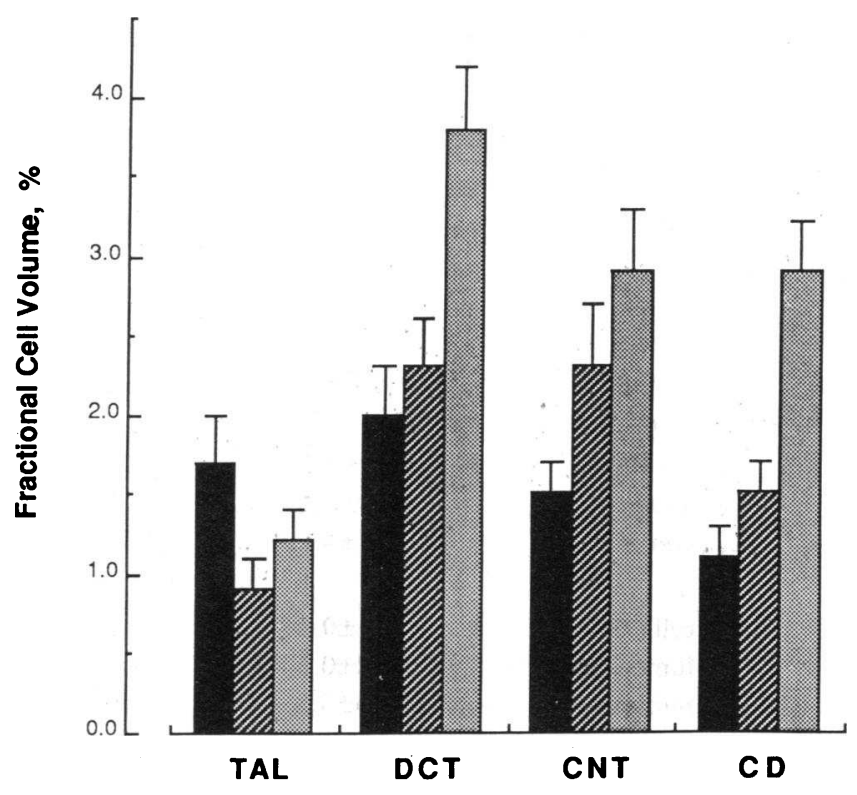

Figure 4. Fractional volumes of tubule cells of TAL, DCT, CNT, and $\mathrm{CD}$. See Table VII for statistical analysis. 
Table VI. Tubule Lengths and Kidney Weights

\begin{tabular}{lcccccc}
\hline \multicolumn{1}{c}{ Treatment } & 1 & 2 & 3 & 1 vs. 2 & 2 vs. 3 & 1 vs. 3 \\
\hline Length $(m m)$ & $2.2 \pm 0.2$ & $2.2 \pm 0.1$ & $2.3 \pm 0.1$ & NS & NS & NS \\
Left kidney wt $(g)$ & $1.54 \pm 0.05$ & $1.32 \pm 0.07$ & $1.30 \pm 0.07$ & NS & NS & $*$ \\
Right kidney wt $(g)$ & $1.44 \pm 0.07$ & $1.31 \pm 0.07$ & $1.28 \pm 0.06$ & NS & NS & NS
\end{tabular}

Treatment 1, high NaCl; treatment 2, low $\mathrm{NaCl}$; treatment 3, furosemide. Length indicates measured tubule length from region of the macula densa to the first confluence with another distal tubule. There were seven left and right kidneys in group 1, seven left and eight right kidneys in group 2, and 15 left and right kidneys in group 3. * indicates $P<0.05$. $P$ values for 1 vs. 2,2 vs. 3, and 1 vs. 3 determined by modified $t$ test as described in Methods.

studies that indicated that sites beyond the DCT are primarily responsible for reducing the urinary concentration of $\mathrm{Na}$ when dietary $\mathrm{NaCl}$ intake is restricted $(4,5,21)$.

In vivo microperfusion was used to estimate the intrinsic ability of the distal tubule to absorb $\mathrm{Na}$ and $\mathrm{Cl}$ independent of changes in luminal fluid flow rate or ion composition. During these experiments, preexisting differences in peritubular fluid ion concentrations were reduced by infusing the same saline solution in all animals. To estimate transport by DCT cells, we used the diuretic CTZ. We have shown previously that this drug blocks all transcellular $\mathrm{Na}$ and $\mathrm{Cl}$ transport by the DCT but does not affect $\mathrm{Na}$ and $\mathrm{Cl}$ transport by the ICT of the rat (13). Based on those results, the fraction of distal $\mathrm{Na}$ and $\mathrm{Cl}$ transport that was inhibited by CTZ was taken as an estimate of transport by DCT cells.

The results of the in vivo microperfusion experiments indicate that dietary $\mathrm{NaCl}$ deprivation does affect the intrinsic ability of the distal tubule to absorb $\mathrm{Na}$ and $\mathrm{Cl}$. When dietary $\mathrm{NaCl}$ intake is severely restricted, the distal tubule is able to transport $\mathrm{Na}$ and $\mathrm{Cl}$ more rapidly. Other investigators, using free-flow micropuncture techniques, have reported that di- etary $\mathrm{NaCl}$ restriction does not affect $\mathrm{Na}$ and $\mathrm{Cl}$ transport by the distal tubule (4-6). These experiments differ from previous investigations of effects of dietary $\mathrm{Na}$ intake in several respects. First, when free-flow micropuncture techniques are used to measure transport rates, changes in luminal $\mathrm{Na}$ and $\mathrm{Cl}$ concentration or flow rate may obscure effects of dietary $\mathrm{NaCl}$ intake. Second, some investigators have measured ion transport rates in the distal tubule only during acute extracellular fluid volume expansion (4). Third, in these experiments, tubules were perfused with an AIF in which the $\mathrm{Na}$ and $\mathrm{Cl}$ concentrations are considerably higher than observed physiologically under most conditions (compare the perfusion solution with early distal fluid obtained by free flow collections, Table II). Thus, results of in vivo microperfusion may not reflect ion transport rates that occur under free flow conditions: rather, they provide an indication of the intrinsic ability of the tubule to transport $\mathrm{Na}$ and $\mathrm{Cl}$. Each of these factors may have obscured differences in transport rates in past experiments.

Another way in which free flow conditions differ from microperfusion is in the relative concentrations of sodium and chloride in tubule fluid. Free flow measurements showed that

Table VII. Fractional Volumes of Tubule Cells and Lumens and Fractional Length of Lumens

\begin{tabular}{|c|c|c|c|c|c|c|}
\hline Treatment & $\begin{array}{c}1 \\
(40 / 5)\end{array}$ & $\begin{array}{c}2 \\
(39 / 4)\end{array}$ & $\begin{array}{c}3 \\
(49 / 5)\end{array}$ & 1 vs. 2 & 2 vs. 3 & 1 vs. 3 \\
\hline \multicolumn{7}{|l|}{ TAL } \\
\hline$V_{\mathrm{v}}$, cell $(\%)$ & $1.7 \pm 0.3$ & $0.9 \pm 0.2$ & $1.2 \pm 0.2$ & NS & NS & NS \\
\hline$V_{\mathrm{v}}$, lumen $(\%)$ & $2.3 \pm 0.5$ & $0.5 \pm 0.1$ & $1.6 \pm 0.2$ & $*$ & $\neq$ & NS \\
\hline$L_{\mathrm{V}}\left(\mathrm{mm} / \mathrm{mm}^{3}\right)$ & $46.6 \pm 7.0$ & $30.6 \pm 5.2$ & $56.9 \pm 7.6$ & NS & $\neq$ & NS \\
\hline \multicolumn{7}{|l|}{ DCT } \\
\hline$V_{\mathrm{v}}$, cell $(\%)$ & $2.0 \pm 0.3$ & $2.3 \pm 0.3$ & $3.8 \pm 0.4$ & NS & $*$ & * \\
\hline$V_{\mathrm{v}}$, lumen $(\%)$ & $1.1 \pm 0.2$ & $0.8 \pm 0.2$ & $1.3 \pm 0.2$ & NS & NS & NS \\
\hline$L_{\mathrm{V}}\left(\mathrm{mm} / \mathrm{mm}^{3}\right)$ & $32.4 \pm 4.5$ & $33.3 \pm 3.9$ & $44.4 \pm 4.6$ & NS & NS & NS \\
\hline \multicolumn{7}{|l|}{ CNT } \\
\hline$V_{\mathrm{v}}$, cell $(\%)$ & $1.5 \pm 0.2$ & $2.3 \pm 0.4$ & $2.9 \pm 0.4$ & NS & NS & $\neq$ \\
\hline$V_{\mathrm{v}}$, lumen $(\%)$ & $1.1 \pm 0.2$ & $1.2 \pm 0.2$ & $1.3 \pm 0.2$ & NS & NS & NS \\
\hline$L_{\mathrm{V}}\left(\mathrm{mm} / \mathrm{mm}^{3}\right)$ & $25.7 \pm 4.1$ & $31.0 \pm 4.5$ & $30.4 \pm 4.9$ & NS & NS & NS \\
\hline \multicolumn{7}{|l|}{$\mathrm{CD}$} \\
\hline$V_{\mathrm{v}}$, cell $(\%)$ & $1.1 \pm 0.2$ & $1.5 \pm 0.2$ & $2.9 \pm 0.3$ & NS & $*$ & $*$ \\
\hline$V_{\mathrm{v}}$, lumen $(\%)$ & $2.2 \pm 0.3$ & $1.7 \pm 0.2$ & $2.1 \pm 0.3$ & NS & NS & NS \\
\hline$L_{\mathrm{V}}\left(\mathrm{mm} / \mathrm{mm}^{3}\right)$ & $24.6 \pm 3.5$ & $33.0 \pm 4.0$ & $31.1 \pm 3.0$ & NS & NS & NS \\
\hline
\end{tabular}

Treatment 1, high NaCl; treatment 2 , low NaCl; treatment 3, furosemide. $V_{\mathrm{v}}$ is fractional volume, $L_{\mathrm{v}}$ is fractional length. Numbers in parentheses indicate number of photographs/number of rats. ${ }^{*}$ indicates $P<0.01{ }^{\ddagger}{ }^{\ddagger}$ indicates $P<0.05$. $P$ values for 1 vs. 2,2 vs. 3 , and 1 vs. 3 determined by modified $t$ test as described in Methods. 

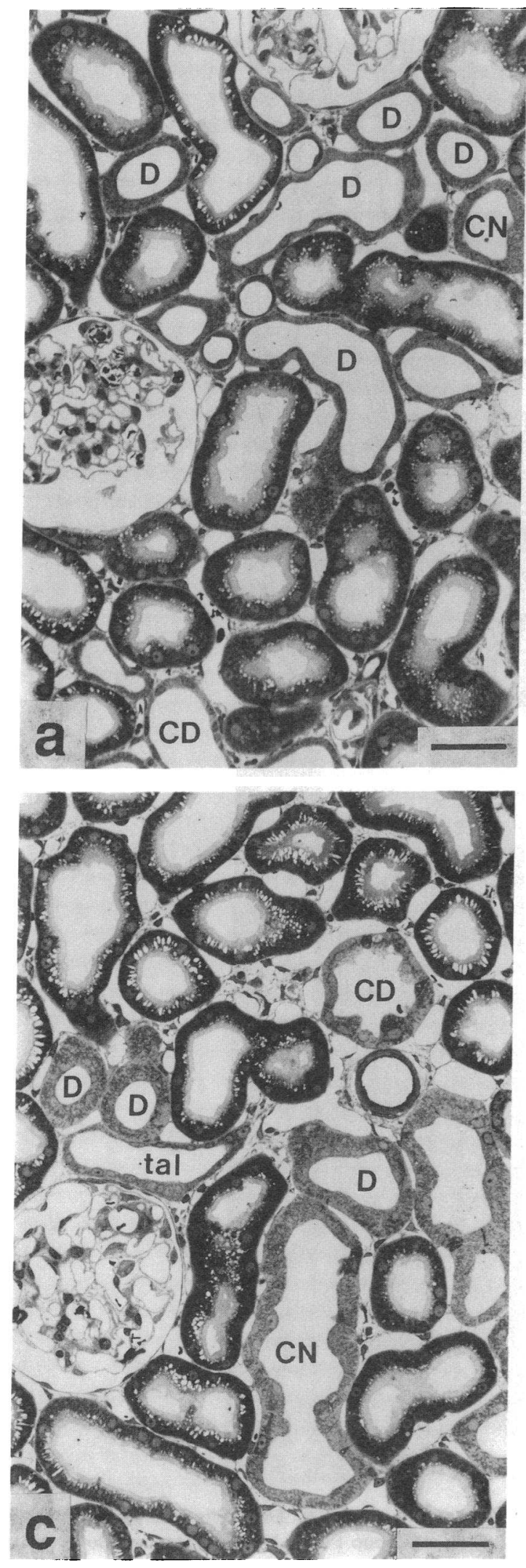

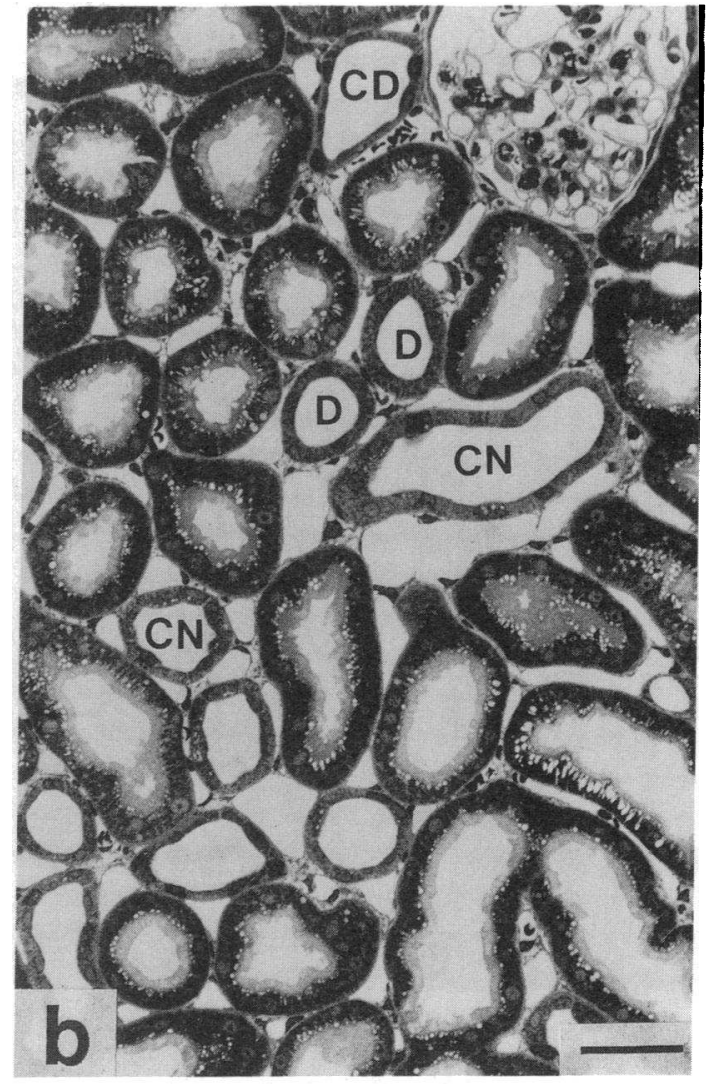

Figure 5. Photomicrographs $(\times 480)$ from kidneys of animals in three groups. Cells of the distal nephron are clearly larger in furosemide treated animals. Hypertrophy of DCT cells, CNT cells, principal cells, and intercalated cells is evident. (A) Group 1 (high $\mathrm{NaCl}$ ); $(B)$ group 2 (low $\mathrm{NaCl}$ ); $(C)$ group 3 (furosemide). tal is thick ascending limb, $\mathrm{D}$ is distal convoluted tubule, $\mathrm{CN}$ is connecting tubule, $\mathrm{CD}$ is collecting duct. Bar, 40 $\mu \mathrm{m}$. dietary $\mathrm{NaCl}$ restriction increased the concentration of unmeasured anions in fluid entering the distal tubule. This value (the tubule fluid anion gap $=[\mathrm{Na}]+[\mathrm{K}]-[\mathrm{Cl}]$ ) provides a rough estimate of the concentration of bicarbonate, phosphate and other nonchloride anions in the tubule fluid. The tubule fluid anion gap was significantly higher in group 2 animals 

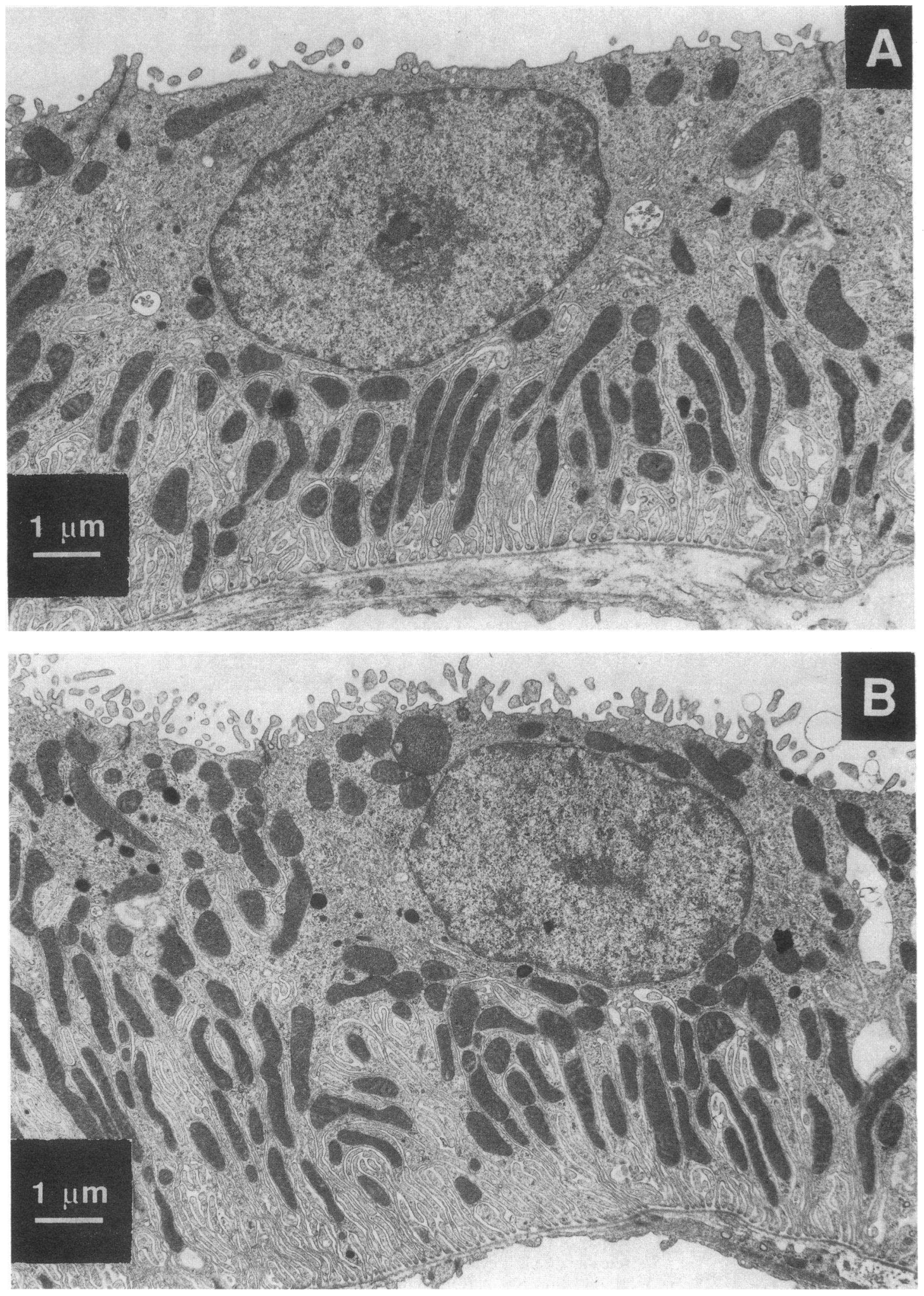

Figure 6. Transmission electron micrographs of DCT cells from kidneys of animals in three groups $(\times 10,000)$. DCT cells from group 3 animals are taller, with increased height of lateral cell processes and larger more rounded nuclei. $(A)$ Group 1 (high $\mathrm{NaCl}) ;(B)$ group 2 (low $\mathrm{NaCl}$ ); (C) group 3 (furosemide). Bar, $1 \mu \mathrm{m}$.

than in groups 1 and 3 (group 1, 10.3 $\pm 1.5 \mathrm{mM}$; group 2, $20.3 \pm 2.4 \mathrm{mM}$; and group $3,9.6 \pm 1.5 \mathrm{mM}, P<0.01)$. This indicates that, when $\mathrm{NaCl}$ intake is low, more of the sodium delivered to the distal tubule is accompanied by anions other than chloride. Rates of $\mathrm{Na}$ transport by the distal tubule depend on the luminal concentrations of both $\mathrm{Na}$ and $\mathrm{Cl}$ (23). A 


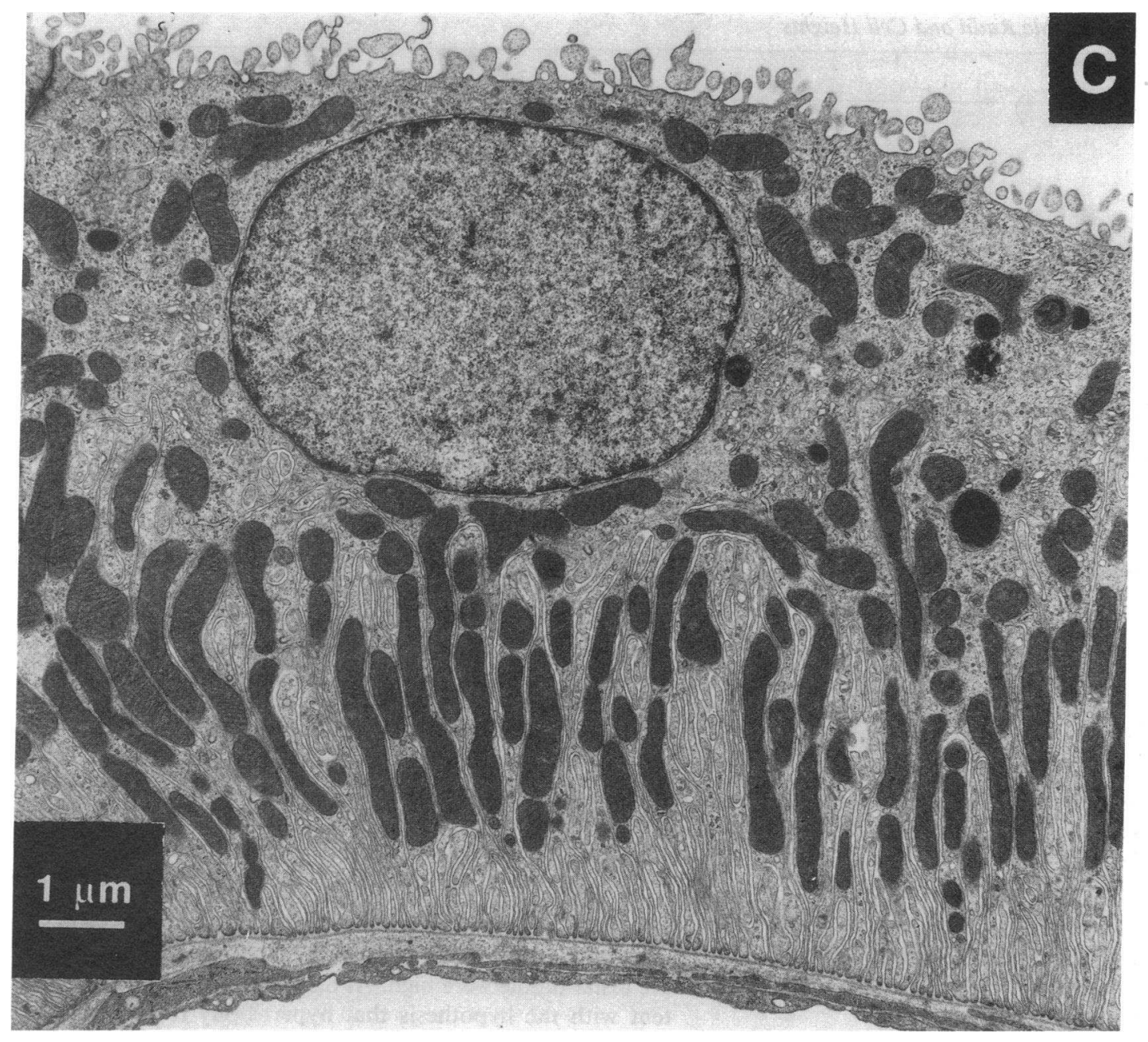

Figure 6 (Continued)

lower luminal $\mathrm{Cl}$ concentration thus reduces the rate of $\mathrm{Na}$ absorption at any particular luminal $\mathrm{Na}$ concentration. The disparity between distal $\mathrm{Na}$ and $\mathrm{Cl}$ concentrations during free flow conditions may also have obscured the effects of dietary $\mathrm{NaCl}$ intake on the ability of distal tubules to reabsorb $\mathrm{Na}$ and $\mathrm{Cl}$ in earlier studies. In these studies, furosemide increased $\mathrm{Na}$ and $\mathrm{Cl}$ transport rates above those observed in high $\mathrm{NaCl}$ diet animals. It also increased the $\mathrm{Na}$ and $\mathrm{Cl}$ transport by whole distal tubules significantly above the (already higher) rates in low $\mathrm{NaCl}$ animals. Like the low $\mathrm{NaCl}$ diet animals, furosemide-treated animals were significantly volume contracted, but in contrast with $\mathrm{NaCl}$ restriction, furosemide increased distal $\mathrm{Na}$ and $\mathrm{Cl}$ delivery significantly. The combination of extracellular fluid volume depletion and high distal $\mathrm{Na}$ and $\mathrm{Cl}$ delivery together may have caused the further increase in intrinsic $\mathrm{Na}$ and $\mathrm{Cl}$ transport ability observed in this group.

The specific mediator of increased transport has not been demonstrated conclusively by these studies, but hormonal factors, changes in plasma electrolyte concentrations, and other alterations in peritubular environment may have contributed. Because all tubules were perfused, luminal factors can be excluded. Hormonal stimulation may have played a role because volume depletion probably stimulated secretion of mineralocorticoid hormones and antidiuretic hormone. Several facts, however, suggest that these hormones did not play a dominant role. First, although aldosterone and antidiuretic hormone have been shown to affect transport by the distal tubule as a whole, they act primarily on epithelium of the ICT. We used CTZ to estimate transport by the DCT and found that transport by this segment was stimulated by furosemide infusion and by $\mathrm{NaCl}$ restriction. Second, preliminary results of Kaissling and Stanton indicate that furosemide infusion increases ion transport by whole distal tubules of rats in whom mineralocorticoid and antidiuretic hormone levels were held constant (24). Third, several other hormones that affect sodium transport by the kidney (such as atrial natriuretic peptide and prostaglandins) apparently do not alter ion transport by the DCT $(2,23)$. Changes in extracellular fluid volume or chloride depletion (metabolic alkalosis) alone also may have contributed to the alterations of ion transport observed in these experiments. In the $\mathrm{CD}$ and loop of Henle, $\mathrm{Cl}$ depletion has been shown to stimulate $\mathrm{NaCl}$ transport $(25,26)$. Chloride depletion has also been reported to affect chloride transport by the distal tubule in vivo (27), but these observations were obtained by free flow micropuncture and may not indicate the intrinsic ability of the tubules to transport ions. In these experiments, plasma chloride concentrations were lower in both groups 2 and 3 than in group 1 (see Table II). These differences may 
Table VIII. Mean Lumen and Tubule Radii and Cell Heights

\begin{tabular}{|c|c|c|c|c|c|c|}
\hline Treatment & 1 & 2 & 3 & 1 vs. 2 & 2 vs. 3 & 1 vs. 3 \\
\hline \multicolumn{7}{|l|}{ TAL } \\
\hline Lumen $(\mu m)$ & $9.2 \pm 1.4$ & $5.0 \pm 0.8$ & $7.9 \pm 0.7$ & $*$ & NS & NS \\
\hline Tubule $(\mu m)$ & $13.2 \pm 1.6$ & $10.5 \pm 0.9$ & $11.1 \pm 0.9$ & NS & NS & NS \\
\hline Cell height $(\mu m)$ & $4.1 \pm 0.5$ & $5.6 \pm 0.7$ & $3.2 \pm 0.3$ & NS & $*$ & NS \\
\hline Epithelial volume $\left(\mathrm{mm}^{3} / \mathrm{mm}\right)^{\ddagger}$ & $361.7 \pm 68.6$ & $299.5 \pm 50.8$ & $217.4 \pm 29.4$ & NS & NS & NS \\
\hline \multicolumn{7}{|l|}{ DCT } \\
\hline Lumen $(\mu m)$ & $8.0 \pm 1.1$ & $6.7 \pm 0.9$ & $7.9 \pm 0.8$ & NS & NS & NS \\
\hline Tubule $(\mu m)$ & $14.6 \pm 1.5$ & $15.5 \pm 1.2$ & $17.0 \pm 1.3$ & NS & NS & NS \\
\hline Cell height $(\mu m)$ & $6.6 \pm 0.7$ & $8.8 \pm 1.0$ & $9.1 \pm 0.7$ & NS & NS & NS \\
\hline Epithelial volume $\left(\mathrm{mm}^{3} / \mathrm{mm}\right)^{\ddagger}$ & $614.5 \pm 85.6$ & $689.9 \pm 80.2$ & $856.9 \pm 87.2$ & NS & NS & NS \\
\hline \multicolumn{7}{|l|}{ CNT } \\
\hline Lumen $(\mu m)$ & $8.7 \pm 1.2$ & $9.3 \pm 1.0$ & $8.7 \pm 1.1$ & NS & NS & NS \\
\hline Tubule $(\mu m)$ & $14.1 \pm 1.8$ & $16.1 \pm 1.6$ & $16.8 \pm 1.8$ & NS & NS & NS \\
\hline Cell height $(\mu m)$ & $5.4 \pm 0.8$ & $6.8 \pm 0.9$ & $8.1 \pm 0.9$ & NS & NS & NS \\
\hline Epithelial volume $\left(\mathrm{mm}^{3} / \mathrm{mm}\right)^{\ddagger}$ & $598.6 \pm 95.6$ & $726.1 \pm 118.6$ & $944.7 \pm 142.6$ & NS & NS & NS \\
\hline \multicolumn{7}{|l|}{$\mathrm{CD}$} \\
\hline Lumen $(\mu m)$ & $14.2 \pm 1.4$ & $11.2 \pm 1.0$ & $12.7 \pm 1.1$ & NS & NS & NS \\
\hline Tubule $(\mu m)$ & $18.0 \pm 1.7$ & $15.6 \pm 1.4$ & $20.2 \pm 1.5$ & NS & NS & NS \\
\hline Cell height $(\mu m)$ & $3.6 \pm 0.4$ & $4.4 \pm 0.7$ & $7.6 \pm 0.6$ & NS & $\S$ & $\S$ \\
\hline Epithelial volume $\left(\mathrm{mm}^{3} / \mathrm{mm}\right)^{\ddagger}$ & $459.8 \pm 62.1$ & $460.6 \pm 71.7$ & $923.4 \pm 94.5$ & NS & $\S$ & $\S$ \\
\hline
\end{tabular}

Treatment 1, high NaCl; treatment 2, low $\mathrm{NaCl}$; treatment 3, furosemide. Number of photographs and number of rats same as Table VII. Radii \pm SE derived from fractional volume and length density data given in Table VII.* indicates $P<0.05 .^{\ddagger}$, epithelial volume per millimeter of tubule length. ${ }^{8}$ indicates $P<0.01$. $P$ values for 1 vs. 2,2 vs. 3 and 1 vs. 3 determined by modified $t$ test as described in Methods.

affect transepithelial ion transport directly; note, however, that determination of plasma electrolyte concentrations was made after $14 \mathrm{~d}$ of dietary treatment and may not reflect precisely the values at the time of micropuncture.

The results of free flow micropuncture experiments indi-

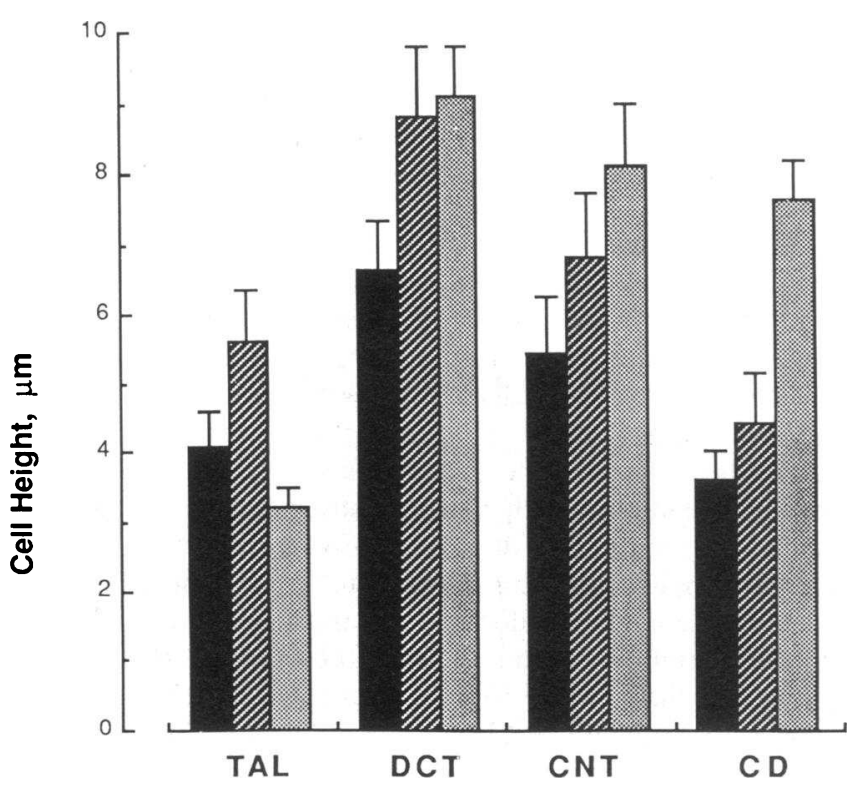

Figure 7. Tubule and luminal radii and cell heights calculated using the fractional volume of lumen, the fractional volume of tubule, fractional volume of cells, the fractional length of lumen, the fractional length of tubule, and the luminal radius as given in Table VII and VIII (see Appendix). See Table VIII for statistical analysis. cate that hypertrophy of distal segments was observed only when the luminal $\mathrm{Na}$ and $\mathrm{Cl}$ concentrations in fluid entering the distal tubule were high. As discussed above, this is consistent with the hypothesis that hypertrophy results from increased rates of transcellular transport. Our results confirm experiments in which chronic furosemide infusion was found to cause hypertrophy of DCT cells of rats (8). The treatment almost certainly provided chronic stimulation of distal $\mathrm{Na}$ and $\mathrm{Cl}$ transport by increasing the concentrations of $\mathrm{Na}$ and $\mathrm{Cl}$ in fluid entering the distal tubule (see Table III). Although animals in group 3 developed hypokalemic metabolic alkalosis, it is unlikely that potassium depletion contributed directly to the hypertrophy of DCT cells. Stanton and co-workers (16) reported that neither potassium adaptation nor depletion affects DCT structure in rats. As discussed above, chloride depletion itself may have contributed to the increased ability to transport sodium and chloride observed in the current experiments.

It is unlikely that hypertrophy of DCT cells is a direct effect of furosemide. The major site of furosemide action is the TAL; furosemide has only a relatively small inhibitory effect on $\mathrm{Na}$ transport in the distal tubule $(14,28)$. Further, Kaissling and co-workers reported that, in rabbits, high $\mathrm{NaCl}$ intake alone caused DCT hypertrophy (7), suggesting that furosemide infusion is not necessary for hypertrophy to develop. In contrast, high $\mathrm{NaCl}$ intake alone did not cause DCT cell hypertrophy in the current experiments. One possible reason for the differences may be found in the results of the free flow micropuncture experiments. Dietary $\mathrm{NaCl}$ intake did not affect the concentration of $\mathrm{Na}$ or $\mathrm{Cl}$ in distal tubule fluid in the current experiments (compare groups 1 and 2, Table III). If chronically elevated $\mathrm{Na}$ and $\mathrm{Cl}$ transport rates are the stimuli for DCT cell hypertrophy, then changes in $\mathrm{NaCl}$ intake within the 
range tested in the current experiments should not cause cell hypertrophy in rats because they do not affect distal $\mathrm{Na}$ concentration significantly. Whether such dietary changes do affect the delivery of $\mathrm{Na}$ and $\mathrm{Cl}$ to distal tubules of rabbits and therefore cause hypertrophy by increasing ion transport rates chronically when dietary $\mathrm{NaCl}$ intake is high, has not been determined.

The tubule cell hypertrophy in the current experiments may be an example of work hypertrophy, as described previously in other segments of the nephron. Fine and Bradley (29) reviewed the evidence that reduction in renal mass causes not only an increase in SNGFR but also proximal tubule cell hypertrophy with increased transport capacity. This is believed to result from increased rates of transcellular $\mathrm{Na}$ transport that occurs in the remaining functional nephrons. Another example of this process is the response of medullary TAL cell to antidiuretic hormone. Bouby et al. (30) showed that medullary TAL cells hypertrophied when rats with hereditary diabetes insipidus were given the vasopressin analogue 1-deamino-8-Darginine-vasopressin. They postulated that such treatment effected hypertrophy by stimulating transcellular $\mathrm{Na}$ and $\mathrm{Cl}$ transport in this segment. The effects of furosemide to reduce the height of cortical TAL cells in this study (Table VIII) is similar to the hypoplasia of medullary TAL cells reported in Brattleboro rats unable to synthesize antidiuretic hormone (31). By blocking the entry of $\mathrm{Na}$ and $\mathrm{Cl}$ into these cells, furosemide probably reduced the transcellular $\mathrm{Na}$ and $\mathrm{Cl}$ traffic and caused a form of disuse atrophy.

Comparison of the effects of the three treatments on cell height, fractional volume, and fractional length of tubule segments (compare Figs. 4 and 6) indicates complex interactions between these variables. Increases in fractional cell volume can be associated with increases or decreases in cell height, depending on changes in tubule length and luminal distension. Although fractional volumes of DCT cells in groups 1 and 2 are similar and significantly lower than fractional DCT volume in group 3, cell height in group 2 is close to cell height in group 3 because the lumen is less distended in the volume contracted animals on low $\mathrm{NaCl}$ intake. These observations highlight pitfalls in the interpretation of cell height alone as an index of tissue mass and suggest that fractional volume is a better indicator of physiologically important changes in cell size.

The results of these experiments may provide an insight into mechanisms of diuretic resistance. Because furosemide administration increases early distal $\mathrm{Na}$ and $\mathrm{Cl}$ concentrations from $<50$ to $>100 \mathrm{mM}$, it stimulates $\mathrm{Na}$ and $\mathrm{Cl}$ transport by the DCT (13). If, as shown in the present experiments, chronic furosemide administration increases the capacity of the distal tubule to absorb $\mathrm{Na}$ and $\mathrm{Cl}$, diuretic effectiveness may attenuate over time. In the normal individual in whom GFR and $\mathrm{Na}$ delivery to the loop of Henle are adequate, distal reabsorption may still be unable to cope with the $30-45 \%$ of filtered $\mathrm{Na}$ and $\mathrm{Cl}$ delivered to that segment. When intense proximal reabsorption is present, however, the smaller increment in delivery to the distal tubule caused by furosemide may be matched by the increment in $\mathrm{Na}$ reabsorptive capacity of the distal tubule with the results that diuretic responsiveness is blunted. Under these circumstances, administration of a thiazide type diuretic may induce a profound diuresis $(32,33)$. Compare, for example, the change in $\mathrm{Na}$ transport rates when $\mathrm{CTZ}$ is added to the lumen in group 1 and group 3 (group $1,83 \mathrm{pmol} / \mathrm{min}$ vs. group 3, $288 \mathrm{pmol} / \mathrm{min}$ ). Clearly, CTZ has a much larger effect after distal tubule adaptation has occurred. When the combination of extracellular fluid volume contraction and reabsorption of $\mathrm{Na}$ and $\mathrm{Cl}$ by the distal tubule limits the effectiveness of a loop diuretic, then the addition of a thiazide-type drug may be especially effective.

In summary, these results suggest that the DCT adapts to chronic alterations of $\mathrm{NaCl}$ intake and to changes in luminal ion concentrations. These intrinsic adaptations are different from the distal tubule's response to acute perturbations in extracellular fluid volume, effects that are mediated primarily by changes in luminal fluid flow rate and ion composition. When $\mathrm{ECF}$ volume is reduced chronically by restricting $\mathrm{NaCl}$ intake, the intrinsic capacity of the DCT to reabsorb $\mathrm{Na}$ and $\mathrm{Cl}$ increases homeostatically, without accompanying morphological changes. When, in addition, distal $\mathrm{Na}$ and $\mathrm{Cl}$ concentrations are increased by chronic furosemide infusion, the intrinsic ability of the distal tubule to absorb $\mathrm{Na}$ and $\mathrm{Cl}$ increases even further, an effect associated with significant hypertrophy of cells throughout the distal nephron. Our results are consistent with the hypothesis that high rates of $\mathrm{Na}$ and $\mathrm{Cl}$ transport initiate growth of cells in the distal nephron and increase ion transport capacity. Other stimuli associated with extracellular fluid volume depletion, however, may also influence the ion transport capacity of cells of the DCT.

\section{Appendix}

The volume densities (fractional volumes) of tubule segments and tubule lumens and the length densities (fractional lengths) of tubule segments were determined in the present experiments by standard morphometric techniques $(34,35)$. Profile counting was done within a rectangular area using the unbiased "forbidden line" rule of Gundersen (36). Because tissue sections were cut with a random orientation and because convoluted tubules course nearly randomly through cortical tissue, a rectangular grid created by equally spaced intersecting horizontal and vertical lines making up 221 counting points was used. The fractional volume of each tubule segment $\left(V_{\mathrm{V}}^{\mathrm{T}}\right)$ was determined by counting the fraction of 221 points overlying the tubule segment. The number of tubule segments included in the rectangular grid area $\left(N_{A}^{\mathrm{T}}\right)$ was used to determine length density $\left(L_{\mathrm{V}}^{\mathrm{T}}\right)$ by the formula $L_{\mathrm{V}}^{\mathrm{T}}=2 N_{\mathrm{A}}^{\mathrm{T}}$ (34). This formulation assumes that tubules are randomly oriented in sections. From $\left(L_{\mathrm{V}}^{\mathrm{T}}\right)$ and $V_{\mathrm{V}}^{\mathrm{T}}$, it is possible to calculate the epithelial volume per $\mathrm{mm}$ of tubule length using the formula, epithelial volume per millimeter $=V_{\mathrm{V}}^{\mathrm{T}} / L_{\mathrm{V}}^{\mathrm{T}}$.

The height of kidney tubule cells is often determined as the mean caliper height, the linear distance between the luminal and basolateral membranes on thin sections $(8,10,17)$. This approach is complicated by at least three kinds of problems. First, the true mean cell height will be equal to cell height measured in this manner only when a tubule is cut exactly perpendicular to its long axis. Second, the cell height of a tubule of constant epithelial volume will vary with differences in luminal distension. Third, because tubule profiles are not selected randomly for analysis, selection bias may influence results. To obtain more accurate estimates of tubule cell height in the present experiments, we used morphometric methods that overcome the problems of selection and cutting angle. This approach assumes that kidney tubules approximate concentric cylinders having radii $R$ and $r$, where $R$ is the radius to the basement membrane of the tubule and $r$ is the radius of the lumen. Cell height is the difference between $R$ and $r$.

Morphometric methods permit measurement of fractional volumes of the luminal compartment $\left(V_{\mathrm{V}}^{\mathrm{L}}\right)$ and the fractional length of the tubule $\left(L_{\mathrm{V}}^{\mathrm{T}}\right)$ as discussed above. Thus, to estimate luminal radius, $r$, using measurements for fractional volume and fractional length, we 
first substitute $V_{\mathrm{V}}^{\mathrm{L}}$ and $L_{\mathrm{V}}^{\mathrm{L}}$ into the general equation for the volume of a cylinder, $V=\pi \cdot r^{2} \cdot L$, and obtain,

$V_{\mathrm{V}}^{\mathrm{L}}=\pi \cdot r^{2} \cdot L_{\mathrm{V}}^{\mathrm{L}}$

We determine $V_{\mathrm{V}}^{\mathrm{L}}$ by point counting. We assume that the fractional length of the lumen $\left(L_{\mathrm{V}}^{\mathrm{L}}\right)$ is equal to the fractional length of the tubule $\left(L_{\mathrm{V}}^{\mathrm{T}}\right)$. Solving for $r$ and substituting the measured length

$r=\sqrt{\frac{V_{\mathrm{V}}^{\mathrm{L}}}{\pi \cdot L_{\mathrm{V}}^{\mathrm{T}}}}$

We next determine $R$, the tubule radius. The sum of the fractional luminal volume $\left(V_{\mathrm{V}}^{\mathrm{L}}\right)$ and the fractional cell volume $\left(V_{\mathrm{V}}^{\mathrm{C}}\right)$ must equal the fractional volume of the tubule as a whole $\left(V_{\mathrm{V}}^{\mathrm{T}}\right), V_{\mathrm{V}}^{\mathrm{C}}+V_{\mathrm{V}}^{\mathrm{L}}=V_{\mathrm{V}}^{\mathrm{T}}$, or $V_{\mathrm{V}}^{\mathrm{C}}+\pi r^{2} L_{\mathrm{V}}^{\mathrm{T}}=\pi R^{2} L_{\mathrm{V}}^{\mathrm{T}}$. Solving for $R$,

$R=\sqrt{\frac{V_{\mathrm{V}}^{\mathrm{C}}+\left(\pi \cdot r^{2} \cdot L_{\mathrm{V}}^{\mathrm{T}}\right)}{\pi \cdot L_{\mathrm{V}}^{\mathrm{T}}}}$

$V_{\mathrm{V}}^{\mathrm{C}}$ (the fractional cell volume) and $L_{\mathrm{V}}^{\mathrm{T}}$ are determined morphometrically. Cell height is then calculated as $R-r$.

\section{Acknowledgments}

We thank Dr. Jeffry Sussman for help with morphological analysis, Dr. John Goffinet for valuable assistance with data analysis, and Dr. Mark Okusa for critical review of the manuscript. We also gratefully acknowledge the assistance of Lillemor Wallmark with preparation of the tissue for histological analysis.

This research was supported by the Veterans Administration and the National Institutes of Health. Dr. Ellison is a Research Associate of the Veterans Administration.

\section{References}

1. Hierholzer, K. 1985. Sodium reabsorption in the distal tubular system. In The Kidney: Physiology and Pathophysiology. D. W. Seldin and G. Giebisch, editors. Raven Press, New York. 1063-1096.

2. Burg, M. B. 1986. Renal handling of sodium, chloride, water, amino acids, and glucose. In The Kidney. B. M. Brenner and F. C. Rector, Jr., editors. 3rd ed. W. B. Saunders Co., Philadelphia, PA. 328-370.

3. Good, D. W., and F. S. Wright. 1979. Luminal influences on potassium section: sodium concentration and fluid flow rate. Am. J. Physiol. 234:F192-F205.

4. Stein, J. H., R. W. Osgood, S. Boonjarern, and J. W. Cox. 1974. Segmental sodium reabsorption in rats with mild and severe volume depletion. Am. J. Physiol. 227:351-359.

5. Peterson, L. N., and F. S. Wright. 1977. Effect of sodium intake on renal potassium excretion. Am. J. Physiol. 233:F225-F234.

6. Malnic, G., R. M. Klose, and G. Giebisch. 1966. Micropuncture study of distal tubular potassium and sodium transport in rat nephron. Am. J. Physiol. 211:529-547.

7. Kaissling, B., and M. Le Hir. 1982. Distal tubular segments of the rabbit kidney after adaptation to altered $\mathrm{Na}$ and $\mathrm{K}$ intake. Cell Tissue Res. 224:469-492.

8. Kaissling, B., S. Bachmann, and W. Kriz. 1985. Structural adaptation of the distal convoluted tubule to prolonged furosemide treatment. Am. J. Physiol. 248:F374-F381.

9. Kaissling, B. 1985. Structural adaptation to altered electrolyte metabolism by cortical distal segments. Fed. Proc. 44:2710-2716.

10. Kaissling, B., and W. Kriz. 1979. Structural analysis of the rabbit kidney. Adv. Anat. Embryol. Cell Biol. 56:1-123.

11. Crayen, M. L., and W. Thoenes. 1978. Architecture and cell structures in the distal nephron of the rat kidney. Cytobiologie. 17:197-211.

12. Kaissling, B. 1982. Structural aspects of adaptive changes in renal electrolyte excretion. Am. J. Physiol. 243:F211-F226.

13. Ellison, D. H., H. Velázquez, and F. S. Wright. 1987. Thiazide-sensitive sodium chloride cotransport in early distal tubule. Am. J. Physiol. 253:F546-F554.
14. Costanzo, L. S. 1985. Localization of diuretic action in microperfused rat distal tubules: $\mathrm{Ca}$ and $\mathrm{Na}$ transport. Am. J. Physiol. 248:F527-F535.

15. Velázquez, H., F. S. Wright, and D. W. Good. 1982. Luminal influences on potassium secretion: chloride replacement with sulfate. Am. J. Physiol. 242:F46-F51.

16. Stanton, B. A., D. Biemesderfer, J. B. Wade, and G. Giebisch. 1981. Structural and functional study of the rat distal nephron: effects of potassium adaptation and depletion. Kidney Int. 19:36-48.

17. Woodhall, P. W., and C. C. Tisher. 1973. Response of the distal tubule and cortical collecting duct to vasopressin in the rat. J. Clin. Invest. 52:3095-3108.

18. Wallenstein, S., C. L. Zucker, and J. L. Fleiss. 1980. Some statistical methods useful in circulation research. Circ. Res. 47:1-9.

19. Khuri, R. N., M. Wiederholt, N. Strieder, and G. Giebisch. 1975. The effect of graded solute diuresis on renal tubular sodium transport in the rat. Am. J. Physiol. 228:1262-1268.

20. Diezi, J., M. Nenniger, and G. Giebsich. 1980. Distal tubular function in superficial rat tubules during volume expansion. Am. J. Physiol. 239:F228-F232.

21. Burg, M. B. Renal handling of sodium, chloride, water, amino acids, and glucose. 1981. In The Kidney. B. M. Brenner and F. C. Rector, Jr., editors. W. B. Saunders Co., Philadelphia, PA. 328-370.

22. Le Hir, M., B. Kaissling, and W. C. Dubach. 1982. Distal tubular segments in the rabbit kidney after adaptation to altered Naand K-intake. II. Changes in Na-K-ATPase activity. Cell Tissue Res. 224:493-504.

23. Velázquez, H., D. W. Good, and F. S. Wright. 1984. Mutual dependence of sodium and chloride absorption by the renal distal tubule. Am. J. Physiol. 247:F904-F911.

24. Kaissling, B., and B. Stanton. 1987. Adaptation of distal tubule to increased fluid delivery. Kidney Int. 31:437. (Abstr.)

25. Galla, J. H., K. A. Kirchner, T. A. Kotchen, and R. G. Luke. 1981. Effect of hypochloremia on loop segment chloride and solute reabsorption in the rat during volume expansion. Kidney Int. 20:569574.

26. Galla, J. H., D. N. Bonduris, K. A. Kirk, and R. G. Luke. 1986. Effect of dietary $\mathrm{NaCl}$ on chloride uptake in rat collecting duct segment. Am. J. Physiol. 251:F454-F459.

27. Galla, J. H., D. N. Bonduris, S. L. Dumbauld, and R. G. Luke. 1984. Segmental chloride and fluid handling during correction of chloride-depletion alkalosis without volume expansion in the rat. J. Clin. Invest. 73:96-106.

28. Velázquez, H., and F. S. Wright. 1986. Effects of diuretic drugs on $\mathrm{Na}, \mathrm{Cl}$, and $\mathrm{K}$ transport by rat renal distal tubue. Am. J. Physiol. 250: F1013-F1023.

29. Fine, L. G., and T. Bradley. 1985. Adaptation of proximal tubular structure and function: insights into compensatory renal hypertrophy. Fed. Proc. 44:2723-2727.

30. Bouby, N., L. Bankir, M. M. Trinh-Trang-Tan, W. M. Minuth, and W. Kriz. 1985. Selective ADH-induced hypertrophy of the medullary thick ascending limb in Brattleboro rats. Kidney Int. 28:456-466.

31. Kriz, W., and L. Bankir. 1982. ADH-induced changes in the epithelium of the thick ascending limb in Brattleboro rats. Ann. NY Acad. Sci. 394:424-434.

32. Oster, J. R., M. Epstein, and S. Smoller. 1983. Combined therapy with thiazide-type and loop diuretic agents for resistant sodium retention. Ann. Intern. Med. 99:405-406.

33. Wollam, G. L., R. C. Tarazi, E. L. Bravo, and H. P. Dustan. 1981. Diuretic potency of combined hydrochlorothiazide and furosemide therapy in patients with azotemia. Am. J. Med. 72:929-936.

34. Loud, A. V., and P. Anversa. 1984. Biology of disease: morphometric analysis of biological processes. Lab. Invest. 50:250-260.

35. Aherne, W. A., and M. S. Dunnil. 1982. Morphometry. Edward Arnold Ltd., London. 205.

36. Gundersen, H. J. G. 1977. Notes on the estimation of the numerical density of arbitrary profiles: the edge effect. J. Microsc. 111:219-223. 